\title{
USE OF COAL DRYING TO REDUCE WATER CONSUMED IN PULVERIZED COAL POWER PLANTS
}

QUARTERLY REPORT FOR THE PERIOD

April 1, 2003 to June 30, 2003

by

Edward K. Levy

Report Issued July 2003

DOE Award Number DE-FC26-03NT41729

\author{
Energy Research Center \\ Lehigh University \\ 117 ATLSS Drive \\ Bethlehem, PA 18015
}




\section{DISCLAIMER}

"This report was prepared as an account of work sponsored by an agency of the United States Government. Neither the United States Government nor any agency thereof, nor any of their employees, makes any warranty, express or implied, or assumes any legal liability or responsibility for the accuracy, completeness, or usefulness of any information, apparatus, product, or process disclosed, or represents that its use would not infringe privately owned rights. Reference herein to any specific commercial product, process, or service by trade name, trademark, manufacturer, or otherwise does not necessarily constitute or imply its endorsement, recommendation, or favoring by the United States Government or any agency thereof. The views and opinions of authors expressed herein do not necessarily state or reflect those of the United States Government or any agency thereof." 


\begin{abstract}
This is the second Quarterly Report for this project. The background and technical justification for the project are described, including potential benefits of reducing fuel moisture, prior to firing in a pulverized coal boiler. A description is given of the equipment, instrumentation and procedures being used for the fluidized bed drying experiments. Results of drying tests performed with North Dakota lignite, having a 6.35 $\mathrm{mm}(1 / 4 ")$ top size, are presented. The experiments were performed with a $381 \mathrm{~mm}\left(15^{\prime \prime}\right)$ settled bed depth, with inlet air and in-bed heater surface temperatures ranging from 43 to $66^{\circ} \mathrm{C}$, with superficial air velocity ranging from $0.2 \mathrm{~m} / \mathrm{s}$ to $1.65 \mathrm{~m} / \mathrm{s}$, and with rate of heat transfer from the in-bed tube bundle to the lignite varying from 0 to $140 \frac{\mathrm{W}}{\mathrm{kg} \text { wet coal }}$. Drying rate is shown to be a strong function of air velocity, drying temperature and rate of in-bed heat transfer.
\end{abstract}




\section{TABLE OF CONTENTS}

Page

$\begin{array}{ll}\text { INTRODUCTION } & 1\end{array}$

Background 1

Previous Work 3

This Investigation $\quad 5$

Task 1: Fabricate and Instrument Equipment 5

Task 2: Perform Drying Experiments 5

Task 3: Develop Drying Models and Compare to Experimental Data 6

Task 4: Drying System Design 6

Task 5: Analysis of Impacts on Unit Performance and Cost of Energy 6

$\begin{array}{lr}\text { EXPERIMENTAL } & 7\end{array}$

Test Apparatus $\quad 7$

Test Procedure $\quad 8$

$\begin{array}{ll}\text { Results and Discussion } & 9\end{array}$

Repeatability 13

Data Consistency 14

Effect of Drying Temperature and In-Bed Heat Flux 15

$\begin{array}{ll}\text { DRYING MODELS } & 22\end{array}$

CONCLUSIONS

$\begin{array}{ll}\text { REFERENCES } & 23\end{array}$

$\begin{array}{ll}\text { NOMENCLATURE } & 23\end{array}$ 


\section{LIST OF FIGURES}

Figure

$\underline{\text { Page }}$

1 Schematic of Plant Layout, Showing Air Heater and Coal

2 Dryer (Version 1)

2 Schematic of Plant Layout, Showing Air Heater and Coal Dryer (Version 2)

3 The Effects of Coal Moisture on Cooling Tower Makeup Water

Improvement in Net Unit Heat Rate Versus Reduction in Coal

4 Moisture Content

$5 \quad$ Project Schedule

$6 \quad$ Sketch of Experimental Bed Setup

Size Distribution of the Coal

$8 \quad$ Moisture Content Versus Time

9 Relationship Between $\Gamma$ and $y$

Drying Rate Versus Velocity - Repeatability Tests

12 Drying Rate Versus Velocity and Inlet Air Temperature

13 Drying Rate Versus Velocity and Heat Flux

14 Drying Rate Versus Velocity, Temperature and Heat Flux

15 Coal Moisture Versus Time

17 Bed Temperature Versus Time

18 Outlet Specific Humidity Versus Time 


\section{LIST OF FIGURES (continued)}

Figure

Page

20

$T_{\text {bed }}$ Versus $T_{\text {air,in }}$

20

21

$\omega_{\text {out }}$ Versus $T_{\text {air,in }}$

21

22

$\mathrm{T}_{\text {bed }}$ Versus $\mathrm{Q} / \mathrm{m}$

21 


\section{LIST OF TABLES}

$\underline{\text { Table }}$

1

Procedure for Drying Tests

2

Drying Conditions $\underline{\text { Page }}$

9

12 


\section{INTRODUCTION}

\section{Background}

Low rank fuels such as subbituminous coals and lignites contain significant amounts of moisture compared to higher rank coals. Typically, the moisture content of subbituminous coals ranges from 15 to 30 percent, while that for lignites is between 25 and 40 percent.

High fuel moisture has several adverse impacts on the operation of a pulverized coal generating unit. High fuel moisture results in fuel handling problems, and it affects heat rate, mass rate (tonnage) of emissions, and the consumption of water needed for evaporative cooling.

This project deals with lignite and subbituminous coal-fired pulverized coal power plants, which are cooled by evaporative cooling towers. In particular, the project involves use of power plant waste heat to partially dry the coal before it is fed to the pulverizers. Done in a proper way, coal drying will reduce cooling tower makeup water requirements and also provide heat rate and emissions benefits.

The technology addressed in this project makes use of the hot circulating cooling water leaving the condenser to heat the air used for drying the coal (Figure 1). The temperature of the circulating water leaving the condenser is usually about $49^{\circ} \mathrm{C}$ $\left(120^{\circ} \mathrm{F}\right)$, and this can be used to produce an air stream at approximately $43^{\circ} \mathrm{C}\left(110^{\circ} \mathrm{F}\right)$. Figure 2 shows a variation of this approach, in which coal drying would be accomplished by both warm air, passing through the dryer, and a flow of hot circulating cooling water, passing through a heat exchanger located in the dryer. 


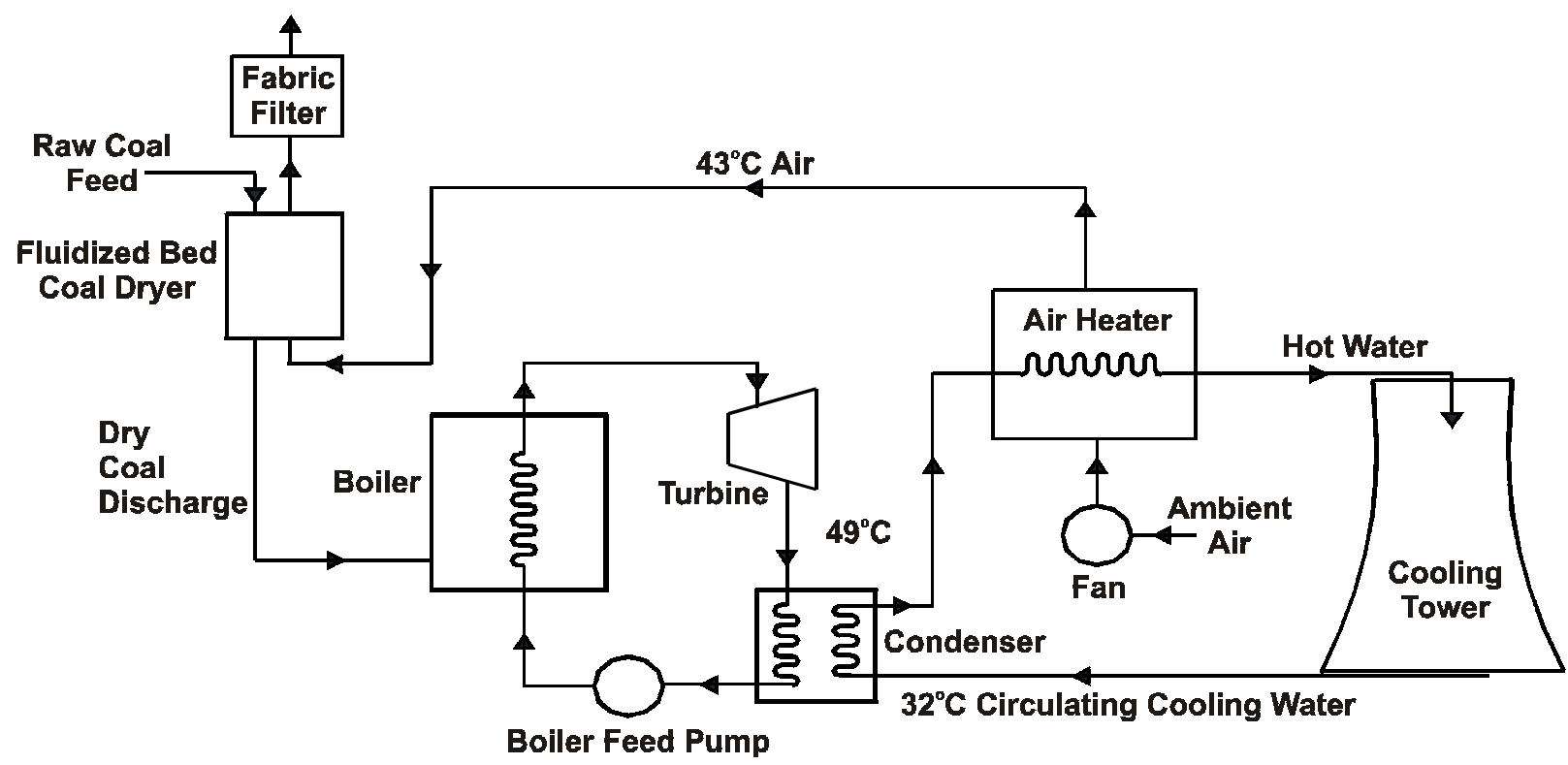

Figure 1: Schematic of Plant Layout, Showing Air Heater and Coal Dryer (Version 1)

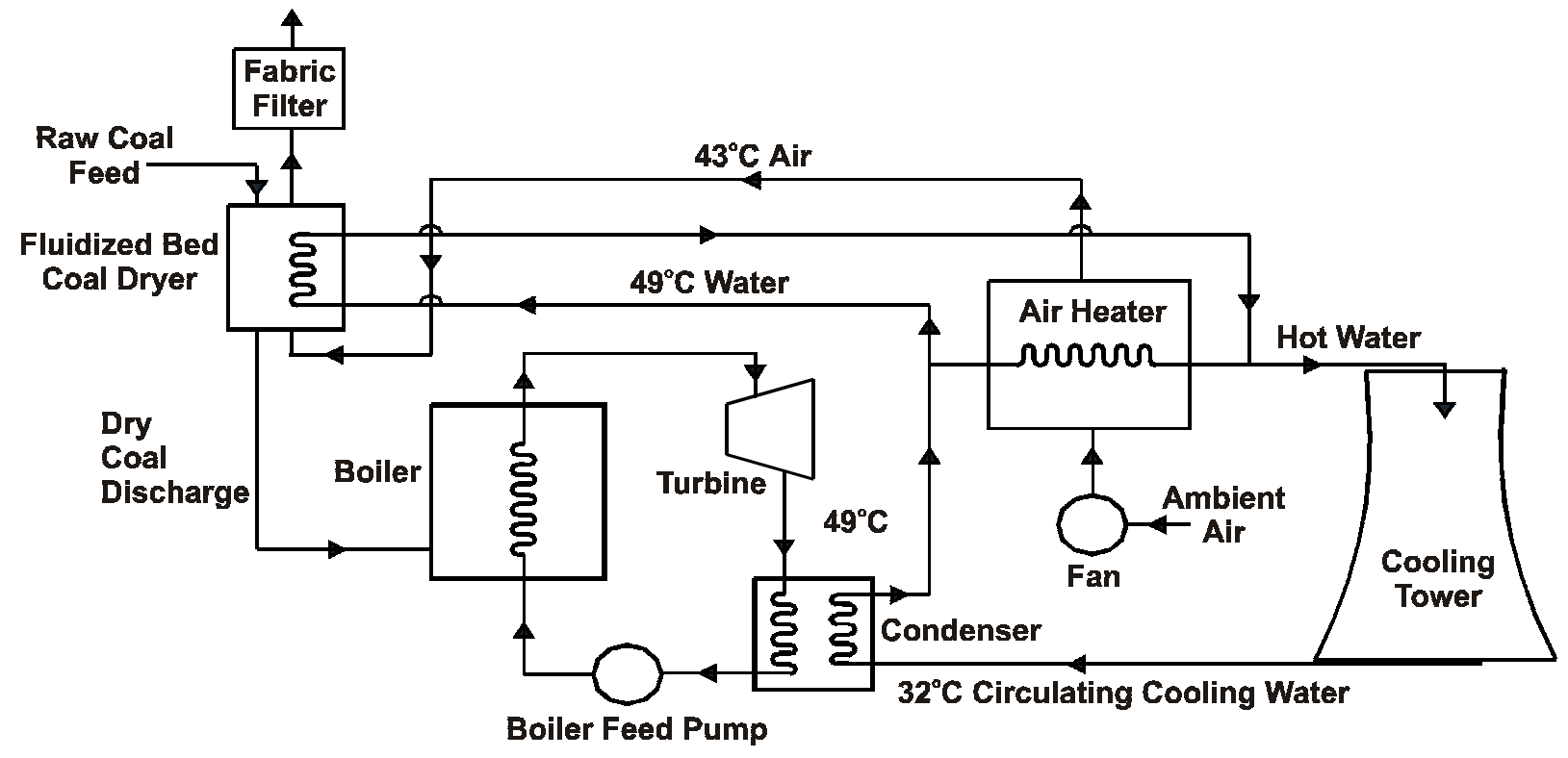

Figure 2: Schematic of Plant Layout, Showing Air Heater and Coal Dryer (Version 2) 


\section{Previous Work}

Two of the investigators (Levy and Sarunac) have been involved in work with the Great River Energy Corporation on a study of low temperature drying at the Coal Creek Generating Station in Underwood, North Dakota. Coal Creek has two units with total gross generation exceeding 1,100 MW. The units fire a lignite fuel containing approximately 40 percent moisture and 12 percent ash. Both units at Coal Creek are equipped with low $\mathrm{NO}_{x}$ firing systems and have wet scrubbers and evaporative cooling towers.

The project team performed a theoretical analysis to estimate the impact on cooling water makeup flow of using hot circulating water to the cooling tower to heat the drying air and to estimate the magnitude of heat rate improvement that could be achieved at Coal Creek Station by removing a portion of the fuel moisture. The results show that drying the coal from 40 to 25 percent moisture will result in reductions in makeup water flow rate from 5 to 7 percent, depending on ambient conditions (Figure 3). For a $550 \mathrm{MW}$ unit, the water savings are predicted to range from $1.17 \times 10^{6}$ liters/day $\left(0.3 \times 10^{6}\right.$ gallons/day) to $4.28 \times 10^{6}$ liters/day $\left(1.1 \times 10^{6}\right.$ gallons/day $)$. The analysis also shows the heat rate and the $\mathrm{CO}_{2}$ and $\mathrm{SO}_{2}$ mass emissions will all be reduced by about 5 percent (Ref. 1).

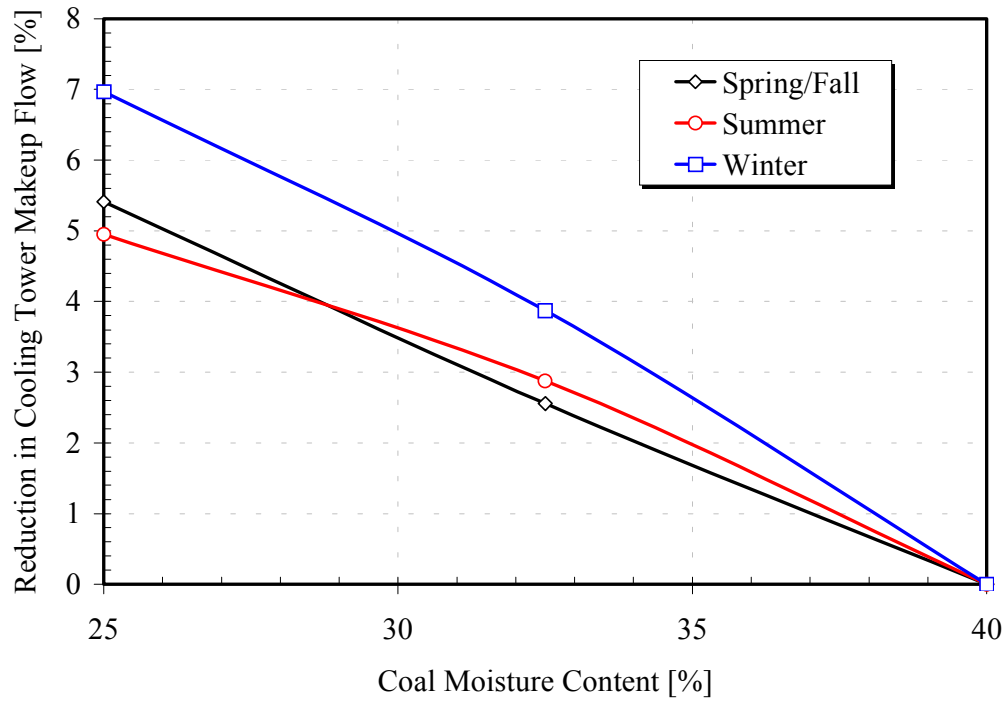

Figure 3: The Effects of Coal Moisture on Cooling Tower Makeup Water 
A coal test burn was conducted at Coal Creek Unit 2 in October 2001 to determine the effect on unit operations. The lignite was dried for this test by an outdoor stockpile coal drying system. On average, the coal moisture was reduced by 6.1 percent, from 37.5 to 31.4 percent. Analysis of boiler efficiency and net unit heat rate showed that with coal drying, the improvement in boiler efficiency was approximately 2.6 percent, and the improvement in net unit heat rate was 2.7 to 2.8 percent. These results are in close agreement with theoretical predictions (Figure 4). The test data also showed the fuel flow rate was reduced by 10.8 percent and the flue gas flow rate was reduced by 4 percent. The combination of lower coal flow rate and better grindability combined to reduce mill power consumption by approximately 17 percent. Fan power was reduced by 3.8 percent due to lower air and flue gas flow rates. The average reduction in total auxiliary power was approximately 3.8 percent (Ref. 1).

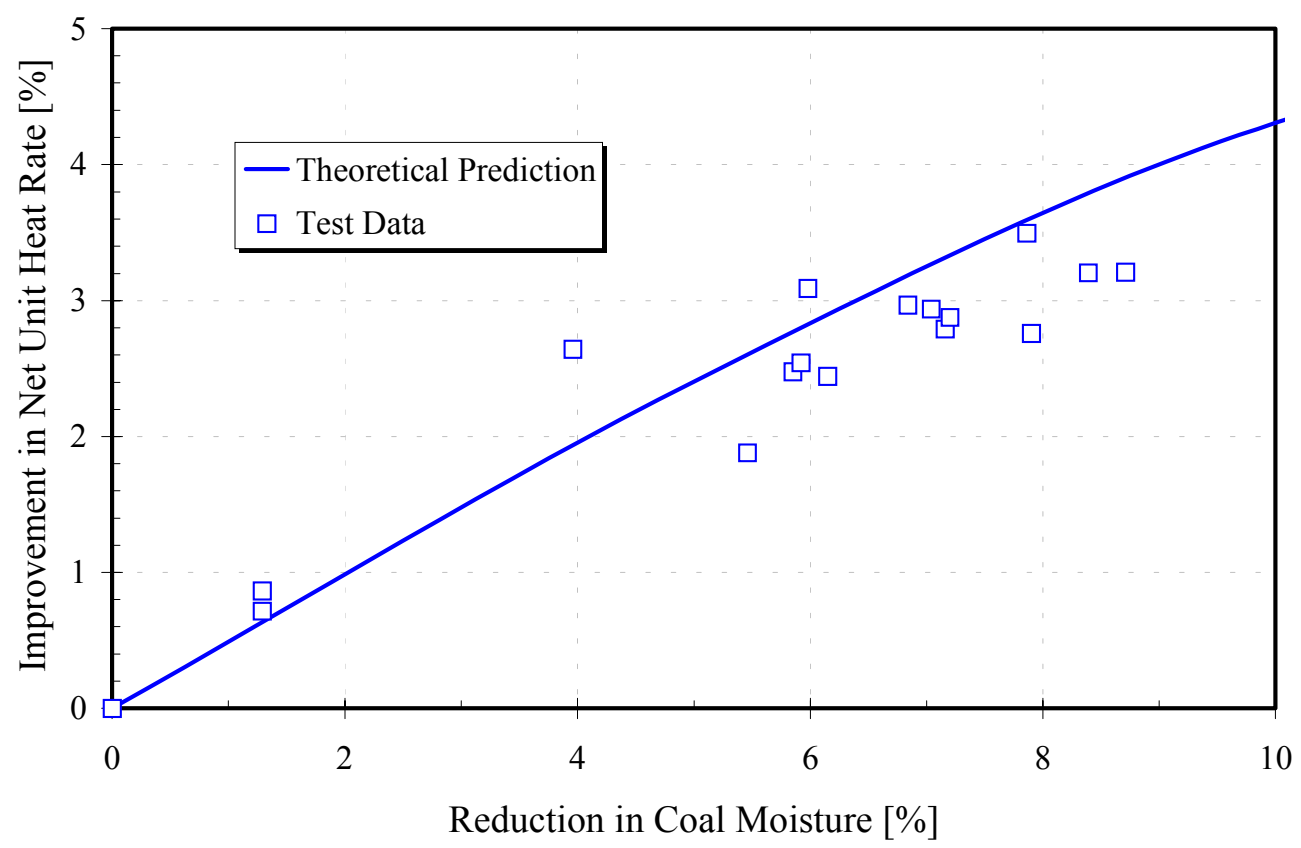

Figure 4: Improvement in Net Unit Heat Rate Versus Reduction in Coal Moisture Content 


\section{This Investigation}

Theoretical analyses and coal test burns performed at a lignite fired power plant show that by reducing the fuel moisture, it is indeed possible to improve boiler performance and unit heat rate, reduce emissions and reduce water consumption by the evaporative cooling tower. The economic viability of the approach and the actual impact of the drying system on water consumption, unit heat rate and stack emissions will depend critically on the design and operating conditions of the drying system.

The present project is evaluating two alternatives (fluidized and fixed bed dryer designs) for the low temperature drying of lignite and Power River Basin (PRB) coal. Drying studies are being performed to gather data and develop models on drying kinetics. In addition, analyses are being carried out to determine the relative costs and performance impacts (in terms of heat rate, cooling tower water consumption and emissions) of these two drying options, along with the development of an optimized system design and recommended operating conditions.

The project is being carried out in five tasks:

\section{Task 1: Fabricate and Instrument Equipment}

Laboratory scale fixed bed and fluidized bed drying systems will be designed, fabricated and instrumented in this task.

\section{Task 2: Perform Drying Experiments}

The experiments will be carried out with both lignite and PRB coals, while varying superficial air velocity, inlet air temperature and specific humidity. In the fluid bed experiments, batch bed experiments will be run with different particle size distributions. The fixed bed experiments will include a range of coal top sizes. Bed depths will be varied for both the fixed and fluidized bed tests. 


\section{Task 3: Develop Drying Models and Compare to Experimental Data}

In this task, the laboratory drying data will be compared to equilibrium and kinetic models to develop models suitable for evaluating tradeoffs between dryer designs.

\section{Task 4: Drying System Design}

Using the kinetic data and models from Tasks 2 and 3, both fluidized bed and packed bed dryers will be designed for $600 \mathrm{MW}$ lignite and PRB coal-fired power plants. Designs will be developed to dry the coal by various amounts. Auxiliary equipment such as fans, water to air heat exchangers, dust collection system and coal crushers will be sized, and installed capital costs and operating costs will be estimated.

\section{Task 5: Analysis of Impacts on Unit Performance and Cost of Energy}

Analyses will be performed to estimate the effects of dryer operation on cooling tower makeup water, unit heat rate, auxiliary power, and stack emissions. The cost of energy will be estimated as a function of the reduction in coal moisture content. Cost comparisons will be made between dryer operating conditions (for example, coal particle feed size to fluidized beds and superficial air velocity for both fluidized bed and fixed bed dryers) and between dryer type.

The project was initiated on December 26, 2002. The project schedule is shown in Figure 5. 


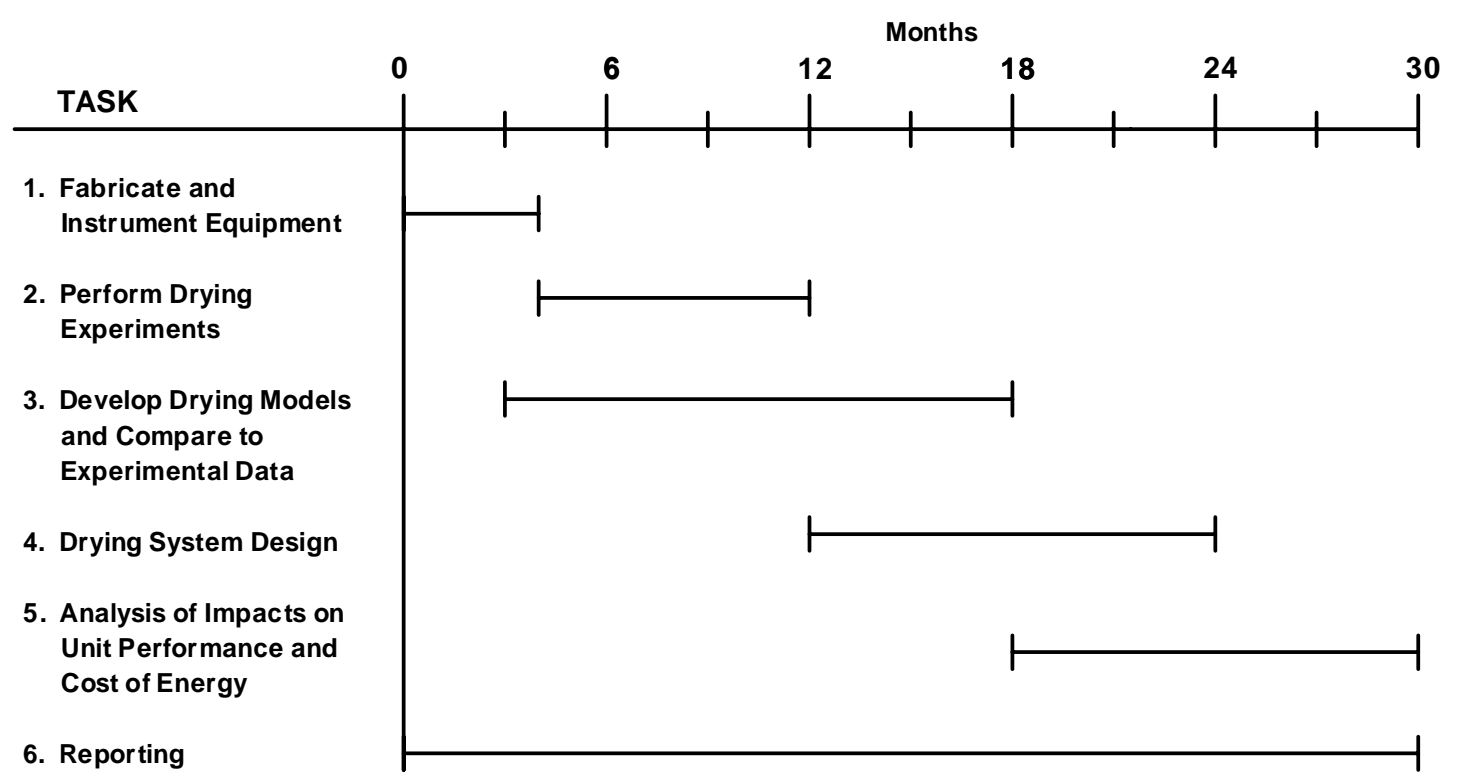

Figure 5: Project Schedule

\section{EXPERIMENTAL}

\section{Test Apparatus}

The drying experiments are being performed in the Energy Research Center's Fluidized Bed Laboratory. The bed vessel is $152.4 \mathrm{~mm}$ (6") in diameter, with a 1372 $\mathrm{mm}$ (54") column and a sintered powder metal distributor plate. The air and entrained coal particles pass through a filter bag before the air is discharged from the apparatus (Figure 6). Compressed air used in the experiments flows though a rotameter and an air heater before entering the plenum. Operating at $1.6 \mathrm{~m} / \mathrm{s}$ of superficial air velocity in the $152.4 \mathrm{~mm}$ (6-inch) diameter bed, the electrically heated, air heater can attain a maximum steady state temperature of $66^{\circ} \mathrm{C}\left(150^{\circ} \mathrm{F}\right)$. 


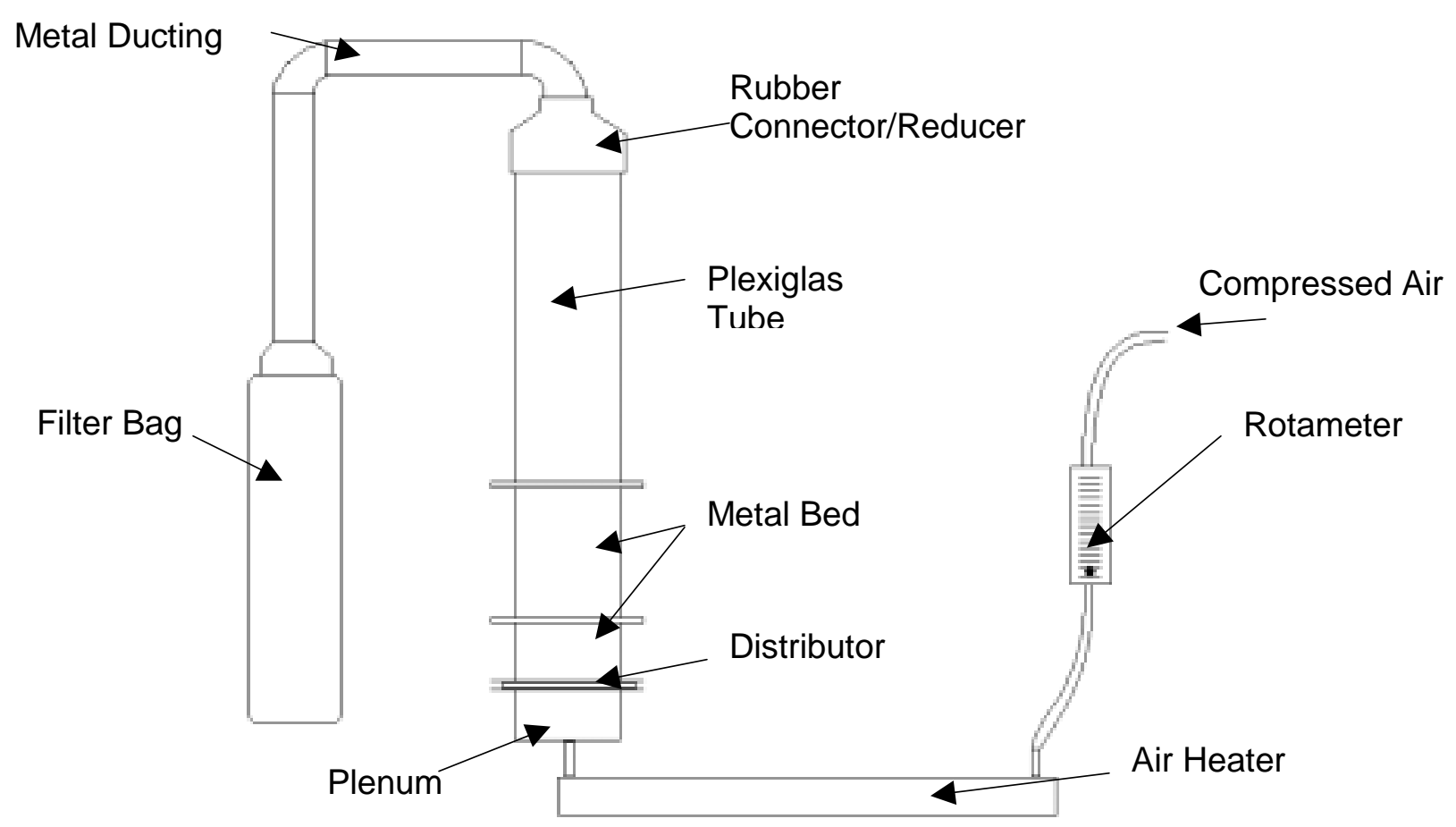

Figure 6: Sketch of Experimental Bed Setup

Thermocouples inserted through the bed wall are used to measure vertical distribution of bed temperature. A horizontal bundle of eighteen $469.9 \mathrm{~mm}(1 / 2$ ") diameter electric heating elements is used to provide in-bed heating. The heaters are located in the region from $51 \mathrm{~mm}$ (2") to $304.8 \mathrm{~mm}$ (12") above the distributor and are instrumented with thermocouples to indicate heater surface temperature. By controlling power to the heaters, the heater surface temperature can be operated in a range from $38^{\circ} \mathrm{C}\left(100^{\circ}\right)$ to $65.6^{\circ} \mathrm{C}\left(150^{\circ} \mathrm{F}\right)$. At a given heater surface temperature, total heat flux to the bed can be reduced from the maximum by disconnecting selected heaters from the power supply.

\section{Test Procedure}

Batch bed drying tests were performed to determine the effect of superficial air velocity, inlet air and heater surface temperatures, and rate of heat transfer from the inbed tube bundle to the coal on rate of drying. These tests were performed with a 
packed bed depth of $381 \mathrm{~mm}$ (15"), and with specific humidity of the inlet air ranging from 0.002 to 0.008 . Small samples of the coal were removed from the bed during the drying tests and coal moisture was measured. This was determined by drying samples of the coal in crucibles in an oven at $110^{\circ} \mathrm{C}$ for 5 to 6 hours, and weighing the samples before and after drying. The complete test procedure used in these experiments is described in Table 1.

\section{Table 1}

Procedure for Drying Tests

1. With no coal in bed, turn on compressor, set air flow to desired value, turn on air preheater and allow system to reach steady-state at desired temperature. Measure inlet relative humidity and dry bulb temperature of air.

2. Once air is at steady-state, turn off air preheater and air flow, load coal into bed, turn on all heaters and air flow to appropriate values, start stopwatch, and record pressure of inlet air from pressure gauge above rotameter.

3. Begin recording temperatures after 5 minutes, collect small samples of lignite from bed, measure wet and dry bulb temperatures at exit of bed, record values for temperature readings at each assigned thermocouple, adjust voltage regulators for the heaters so that surface temperatures remain steady at appropriate values, and repeat this procedure for each time interval on data sheet.

4. At end of test, shut off heaters but keep air flow on to cool the heaters, detach filter bag, load coal samples into crucibles, place crucibles into oven, set to $100^{\circ} \mathrm{C}$, and leave for 5-6 hours or overnight, remove remaining lignite from the bed and weigh it.

5. Analyze results.

\section{Results and Discussion}

The experiments performed in this reporting period were carried out with North Dakota lignite provided by Great River Energy. This had been crushed at the mine to a $6.35 \mathrm{~mm}(1 / 4$ ") top size and shipped to the Energy Research Center in barrels. Typical size distribution is shown in Figure 7. Average particle size, computed as 


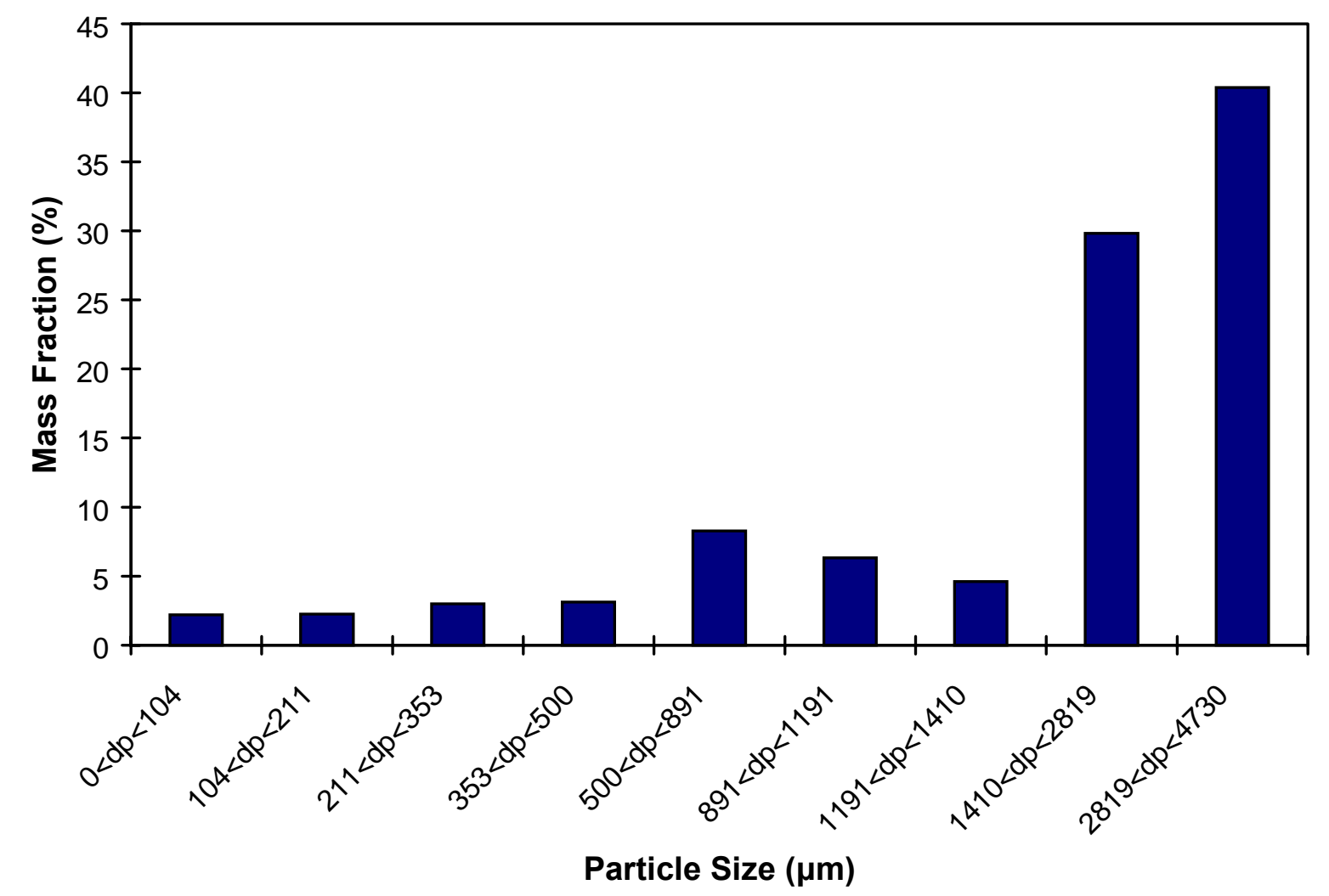

Figure 7: Size Distribution of the Coal

$$
\overline{\mathrm{d}}_{\mathrm{p}}=\frac{1}{\sum \frac{\mathrm{x}_{\mathrm{i}}}{\mathrm{dp}_{\mathrm{i}}}}
$$

where

$$
\begin{aligned}
& x_{i}=\text { mass fraction in size range } i \\
& d p_{i}=\text { average particle size in size range } i \\
& \bar{d}_{p}=\text { average particle size for entire sample. }
\end{aligned}
$$

was $510 \mu \mathrm{m}$ for the first group of tests and $655 \mu \mathrm{m}$ for the second test series. All the tests were performed with a settled bed depth of $0.39 \mathrm{~m}$.

The as received moisture content varied slightly from sample-to-sample, usually ranging from 35 to $38 \%$ (expressed as mass of moisture/mass of as-received fuel) and from 54 to $58 \%$ (expressed as mass of moisture/mass dry fuel). 
During the first minute or two of each test, fines were elutriated from the bed. The drying rate, $\dot{\Gamma}\left(\frac{\mathrm{kg} \mathrm{H}_{2} \mathrm{O}}{\mathrm{kg} \text { dry coal } \times \min }\right)$, presented here is based on the dry coal which remained in the bed after elutriation had occurred and after coal samples had been removed for analysis.

Figure 8 shows the coal moisture content $\Gamma\left(\frac{\mathrm{kg} \mathrm{H}_{2} \mathrm{O}}{\mathrm{kg} \mathrm{dry} \mathrm{coal}}\right)$ as a function of drying time for 6 different drying tests. The corresponding velocities and temperatures are shown in Table 2. These show characteristic drying behavior, with constant rate drying (constant slope) followed by a reduced rate of drying. Note that at the beginning of each test $\Gamma \approx 55$ to 58 percent. $\Gamma$ can related to the moisture content $Y$ obtained from a proximate analysis, where $\mathrm{Y}$ has the units $\left(\frac{\mathrm{kg} \mathrm{H}_{2} \mathrm{O}}{\mathrm{kg} \mathrm{wetcoal}}\right)$. Figure 9 gives the relation between $Y$ and $\Gamma$.

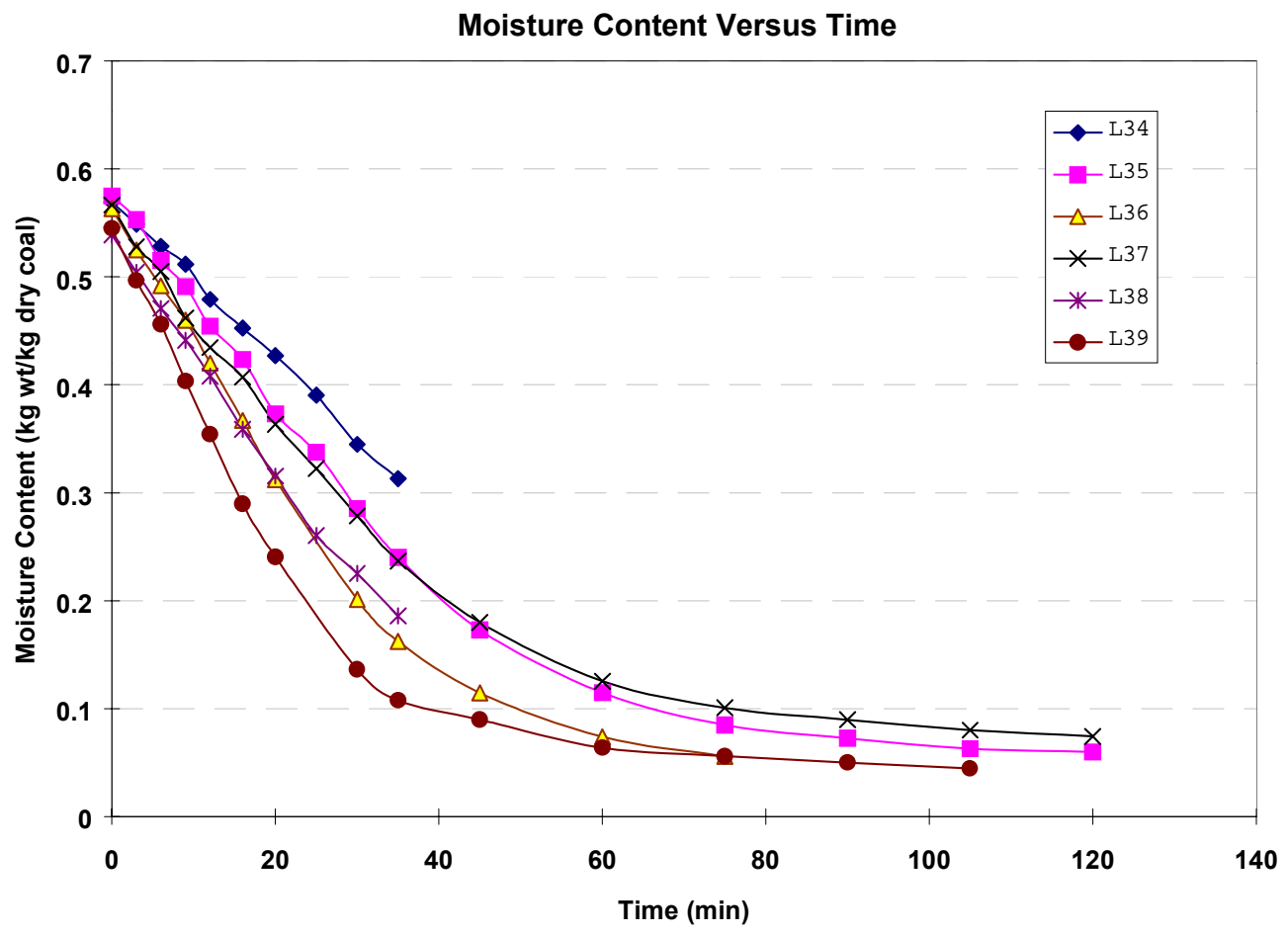

Figure 8: Moisture Content Versus Time 
Table 2

\section{Drying Conditions}

\begin{tabular}{|c|c|c|c|c|c|c|c|c|c|c|c|c|c|}
\hline Test \# & Test Condition & $\mathrm{T}_{\mathrm{a}, \text { in }}$ & $\mathrm{h}_{\mathrm{o}}$ & $\mathrm{U}_{\mathrm{o}}$ & $\mathrm{Q}_{\text {ave }}$ & $\mathrm{Q}_{\mathrm{ave}} / \mathrm{V}_{\text {bed }}$ & Drying Rate & Relative Air Humidity & $\mathrm{Q} / \mathrm{M}_{\mathrm{wet} \text { coal }}$ & $\mathrm{M}_{\mathrm{wet} \text { coal }}$ & $\omega_{\text {out }}$ & $\omega_{\text {in }}$ & $\mathrm{T}_{\mathrm{b}}\left({ }^{\circ} \mathrm{C}\right)$ \\
\hline & & (C) & (m) & $(\mathrm{m} / \mathrm{s})$ & (W) & $\left(\mathrm{W} / \mathrm{m}^{\wedge} 3\right)$ & $\left(\mathrm{kg} / \mathrm{kg}^{*} \min \right)$ & at Exit @ $30 \min (\%)$ & $\mathrm{q} / \mathrm{m}$ & $(\mathrm{Kg})$ & & & \\
\hline 15 & $2 \mathrm{D}, \mathrm{Ta}$, in $=43 \mathrm{C}$ & 43 & 0.39 & 0.60 & 319 & 44441 & 0.0021 & 98 & 65.68 & 3.80 & 0.0182 & & 24 \\
\hline 16 & $2 \mathrm{D}, \mathrm{Ta}$, in $=43 \mathrm{C}$ & 43 & 0.39 & 0.80 & 542 & 75508 & 0.0040 & 87 & 108.61 & 4.04 & 0.0177 & 0.0060 & 26 \\
\hline 17 & $2 \mathrm{D}, \mathrm{Ta}$, in $=43 \mathrm{C}$ & 43 & 0.39 & 1.65 & 529 & 73697 & 0.0098 & 60 & 116.55 & 3.45 & 0.0143 & 0.0060 & 27 \\
\hline 18 & $2 \mathrm{D}, \mathrm{Ta}$, in $=43 \mathrm{C}$ & 43 & 0.39 & 1.02 & 647 & 90136 & 0.0077 & 62 & 137.79 & 3.67 & 0.0176 & 0.0023 & 26 \\
\hline 19 & $2 \mathrm{D}, \mathrm{Ta}$, in $=43 \mathrm{C}$ & 43 & 0.39 & 1.22 & 661 & 92086 & 0.0081 & 71 & 132.09 & 3.89 & 0.0159 & 0.0023 & 26 \\
\hline 20 & $2 \mathrm{D}, \mathrm{Ta}$,in $=43 \mathrm{C}$ & 43 & 0.39 & 0.22 & 155 & 21594 & & 88 & & & 0.0197 & 0.0032 & 23 \\
\hline 21 & $2 \mathrm{D}, \mathrm{Ta}$,in $=43 \mathrm{C}$ & 43 & 0.39 & 0.37 & 163 & 22708 & & 87 & & & 0.0172 & 0.0032 & 24 \\
\hline 22 & $2 \mathrm{D}, \mathrm{Ta}$, in $=43 \mathrm{C}$ & 43 & 0.39 & 0.62 & 524 & 73000 & & 72 & & & 0.0166 & 0.0032 & 27 \\
\hline 23 & N/A & 43 & 0.39 & 1.02 & 0 & 0 & 0.0048 & 81 & NA & & 0.0122 & 0.0050 & 19 \\
\hline 24 & N/A & 43 & 0.39 & 1.26 & 0 & 0 & 0.0058 & 76 & NA & & 0.0121 & 0.0062 & 19 \\
\hline 25 & N/A & 43 & 0.39 & 1.53 & 0 & 0 & 0.0067 & 73 & NA & & 0.0120 & 0.0050 & 21 \\
\hline 26 & $2 \mathrm{D}, \mathrm{Ta}$, in $=43 \mathrm{C}$ & 43 & 0.39 & 1.02 & 563 & 78434 & 0.0069 & 75 & 114.84 & 4.07 & 0.0159 & 0.0066 & 23 \\
\hline 27 & $2 \mathrm{D}, \mathrm{Ta}$, in $=43 \mathrm{C}$ & 43 & 0.39 & 1.26 & 542 & 75508 & 0.0072 & 72 & 99.66 & 4.11 & 0.0159 & 0.0066 & 25 \\
\hline 28 & $2 \mathrm{D}, \mathrm{Ta}$,in $=43 \mathrm{C}$ & 43 & 0.39 & 1.51 & 561 & 78155 & 0.0085 & 64 & 109.11 & 3.94 & 0.0147 & 0.0049 & 24 \\
\hline 29 & $3 \mathrm{D}, \mathrm{Ta}$, in $=43 \mathrm{C}$ & 43 & 0.39 & 1.02 & 310 & 43187 & 0.0060 & 78 & 62.53 & 4.16 & 0.0151 & 0.0049 & 22 \\
\hline 30 & $3 \mathrm{D}, \mathrm{Ta}$, in $=43 \mathrm{C}$ & 43 & 0.39 & 1.26 & 310 & 43187 & 0.0070 & 74 & 66.94 & 3.90 & 0.0140 & 0.0041 & 22 \\
\hline 31 & $3 \mathrm{D}, \mathrm{Ta}$, in $=43 \mathrm{C}$ & 43 & 0.39 & 1.56 & 290 & 40401 & 0.0079 & 70 & 60.43 & 3.94 & 0.0137 & 0.0041 & 23 \\
\hline 32 & $2 \mathrm{D}, \mathrm{Ta}$, in $=43 \mathrm{C}$ & 43 & 0.39 & 1.02 & 539 & 75090 & 0.0070 & 75 & 122.42 & 4.03 & 0.0166 & 0.0056 & 23 \\
\hline 33 & $2 \mathrm{D}, \mathrm{Ta}$, in $=43 \mathrm{C}$ & 43 & 0.39 & 1.56 & 509 & 70911 & 0.0085 & 68 & 113.48 & 4.00 & 0.0148 & 0.0056 & 23 \\
\hline 34 & $2 \mathrm{D}, \mathrm{Ta}$, in $=43 \mathrm{C}$ & 43 & 0.39 & 1.14 & 561 & 78155 & 0.0075 & 72 & 128.88 & 3.97 & 0.0161 & 0.0082 & 24 \\
\hline 35 & $2 \mathrm{D}, \mathrm{Ta}$, in $=54 \mathrm{C}$ & 54 & 0.39 & 1.15 & 792 & 110337 & 0.0098 & 62 & 190.00 & 3.83 & 0.0196 & 0.0052 & 36 \\
\hline 36 & $2 \mathrm{D}, \mathrm{Ta}$, in $=66 \mathrm{C}$ & 66 & 0.39 & 1.15 & 961 & 133881 & 0.0127 & 59 & 227.13 & 3.77 & 0.0245 & 0.0036 & 38 \\
\hline 37 & $2 \mathrm{D}, \mathrm{Ta}$, in $=43 \mathrm{C}$ & 43 & 0.39 & 1.56 & 532 & 74115 & 0.0092 & 64 & 143.10 & 3.39 & 0.0141 & 0.0037 & 29 \\
\hline 38 & $2 \mathrm{D}, \mathrm{Ta}$, in $=54 \mathrm{C}$ & 54 & 0.39 & 1.54 & 727 & 101281 & 0.0111 & 51 & 170.03 & 3.80 & 0.0189 & 0.0082 & 29 \\
\hline 39 & $2 \mathrm{D}, \mathrm{Ta}$, in $=66 \mathrm{C}$ & 66 & 0.39 & 1.58 & 591 & 82334 & 0.0155 & 26 & 152.10 & 3.53 & 0.0204 & 0.0046 & 43 \\
\hline
\end{tabular}




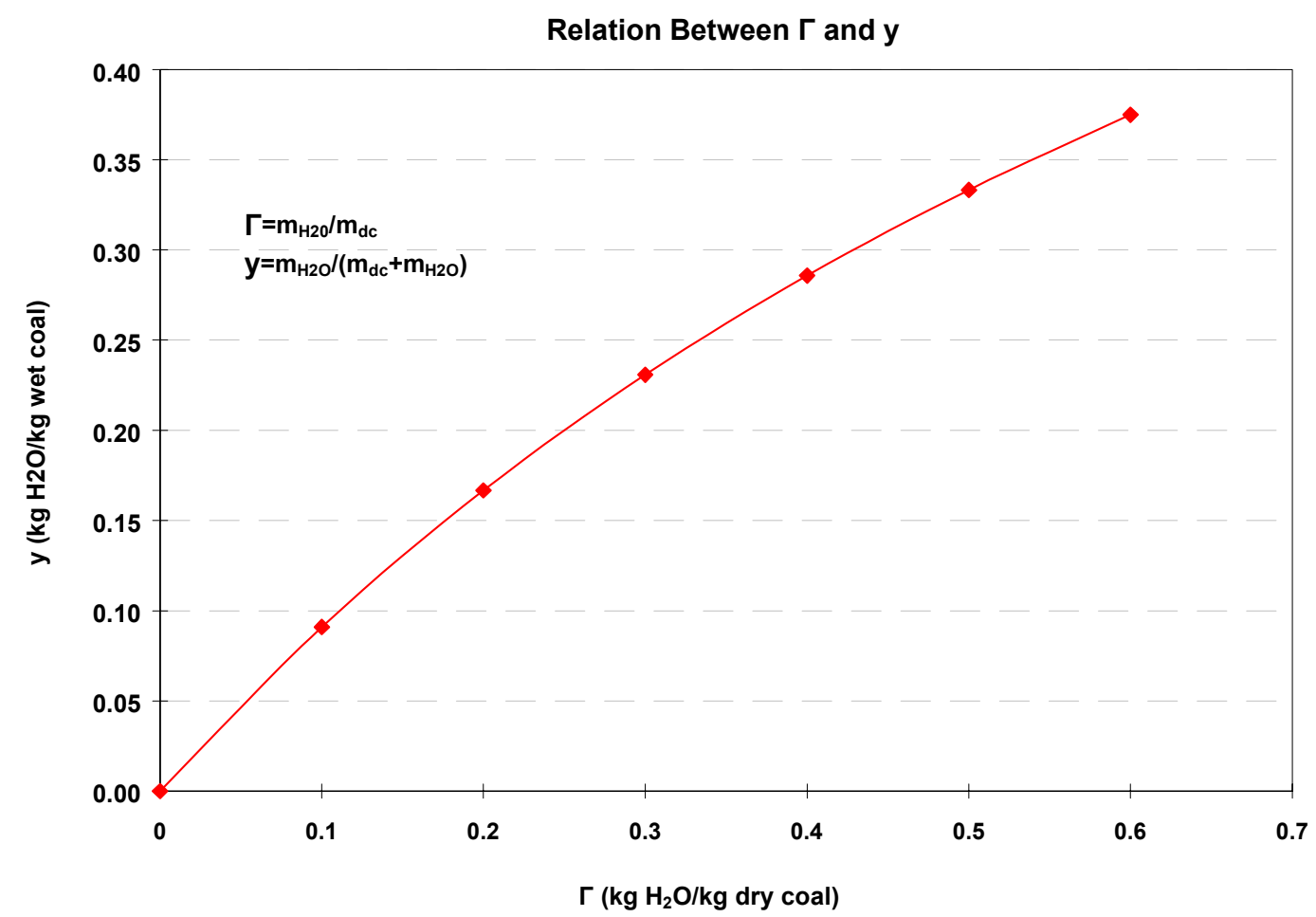

Figure 9: Relationship Between $\Gamma$ and $y$

The superficial air velocities $U_{0}$ are defined as $\frac{\dot{\mathrm{m}}_{\text {air }}}{\rho \mathrm{A}}$

where

$$
\begin{aligned}
& A=\text { Bed Cross Sectional Area Without Tube Bundle } \\
& \rho=\text { Density of Air at Standard T \& P }
\end{aligned}
$$

\section{Repeatability}

Figure 10 shows three data sets for the same temperature conditions $\left[\mathrm{T}_{\text {air in }}=\right.$ $\left.110^{\circ} \mathrm{F}, \mathrm{T}_{\mathrm{TUBE}} \mathrm{WALL}=110^{\circ} \mathrm{F}\right]$ and $\mathrm{U}_{0}=1.02$ to $1.6 \mathrm{~m} / \mathrm{s}$. These replicate data indicate the degree of repeatability of the drying tests when the coal feed has a fixed size distribution. 


\section{Drying Rate Versus Velocity - Repeatability Tests}

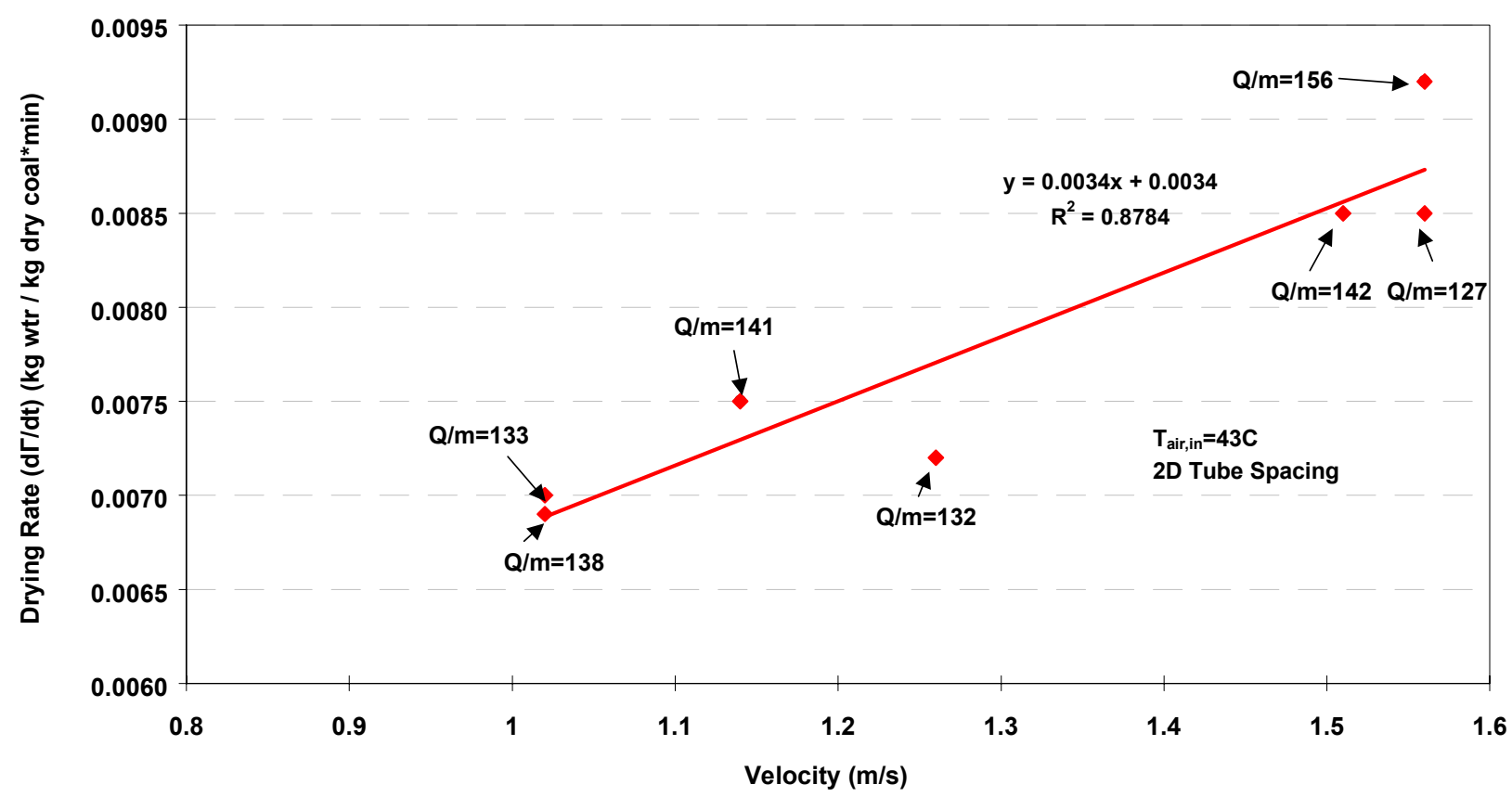

Figure 10: Drying Rate Versus Velocity - Repeatability Tests

\section{Data Consistency}

One way to assess the consistency of the data is to compare the measured values of moisture removed from the coal to the moisture added to the air. The mass balance for $\mathrm{H}_{2} \mathrm{O}$ requires

$$
\mathrm{m}_{\mathrm{DC}} \frac{\mathrm{d} \Gamma}{\mathrm{dt}}=-\dot{\mathrm{m}}_{\mathrm{air}}\left[\omega_{\text {OUT }}-\omega_{\mathrm{IN}}\right]
$$

where

$$
\begin{aligned}
& \omega \quad=\text { Specific Humidity of Air } \\
& \Gamma \quad=\text { Moisture Content of Coal }\left(\frac{\mathrm{kg} \mathrm{H}_{2} \mathrm{O}}{\mathrm{kg} \mathrm{dry} \mathrm{coal}}\right) \\
& \dot{\mathrm{m}}_{\text {air }}=\text { Mass Flow Rate of Dry Air } \\
& \mathrm{m}_{\mathrm{DC}}=\text { Mass of Dry Coal } \\
& \dot{\Gamma} \quad=\frac{\mathrm{d} \Gamma}{\mathrm{dt}}=\text { drying rate }
\end{aligned}
$$


Figure 11 compares $\dot{\Gamma}$ based on coal moisture measurements, to $\dot{\Gamma}$ based on air moisture measurements. The $45^{\circ}$ line indicates perfect agreement. The data show a small bias which ranges from approximately 9 percent at low drying rates to 3 percent at high drying rates.

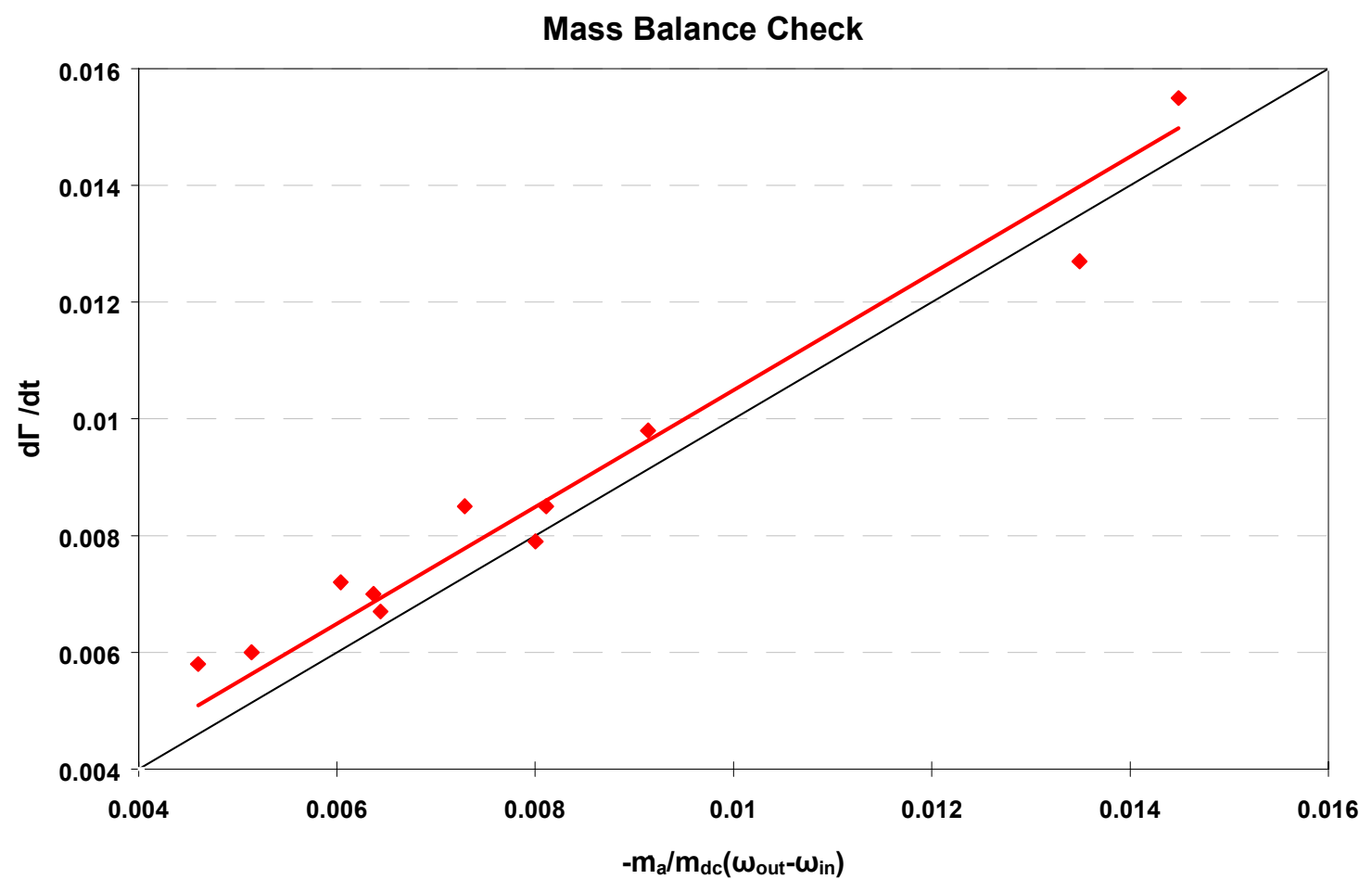

Figure 11: Mass Balance Check

\section{Effects of Drying Temperature and In-Bed Heat Flux}

Figure 12 shows the effect of inlet air and tube wall temperature on drying rate. Figure 13 shows the effect of in-bed heat transfer for fixed inlet air and tube wall temperatures. Drying rate increased almost two-fold as T (air and tube wall) increased from $110^{\circ}$ to $150^{\circ} \mathrm{F}$. However, in-bed heat transfer had a smaller effect on $\dot{\Gamma}$ as the inbed tube spacing went from $2 \mathrm{D}$ to $\infty$ (or $\frac{\dot{Q}}{m}=140$ to $\frac{\dot{Q}}{m}=0$ ) at constant drying temperature. All the data are compared in Figure 14. 


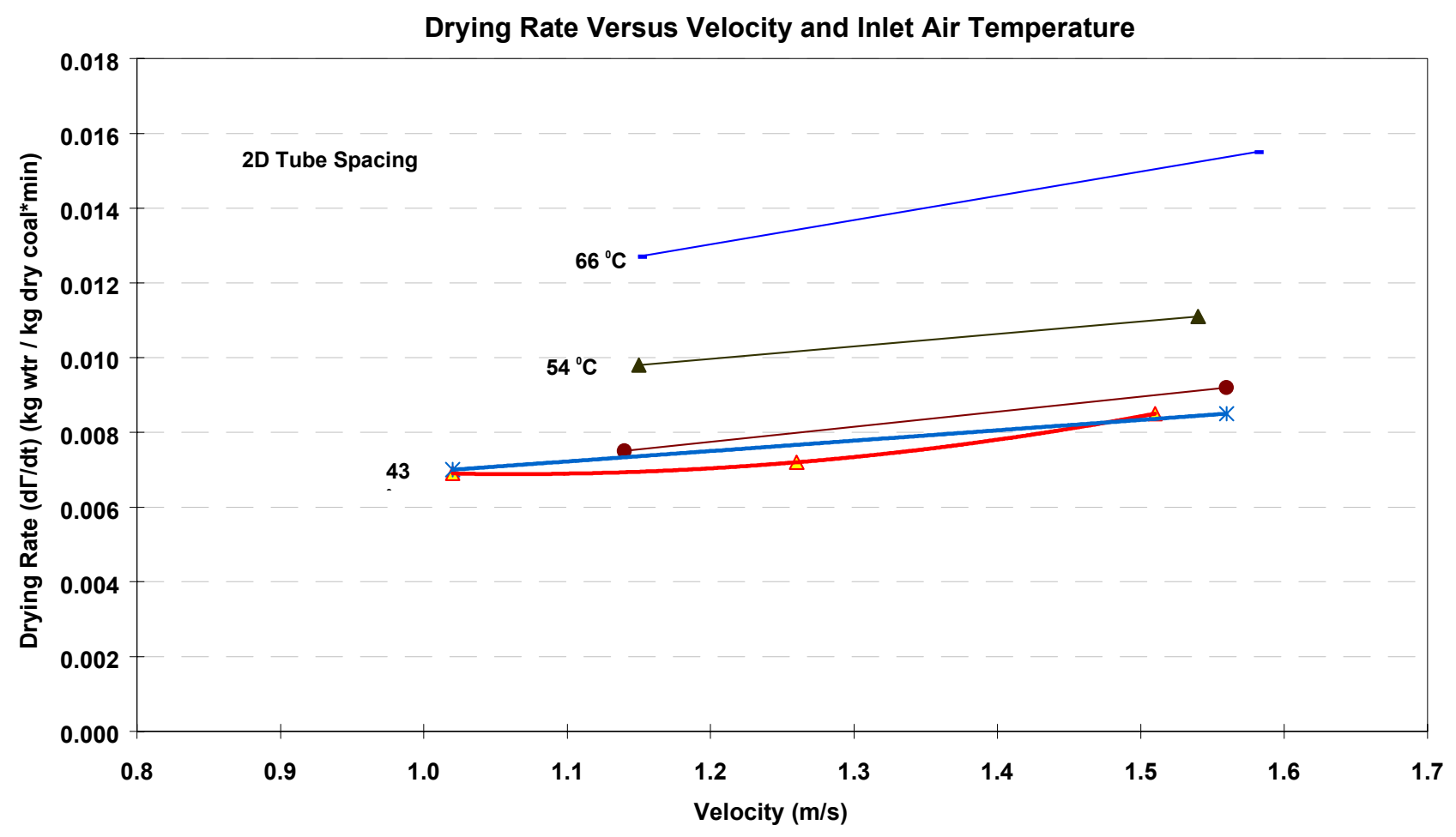

Figure 12: Drying Rate Versus Velocity and Inlet Air Temperature

Drying Rate Versus Velocity and Heat Flux

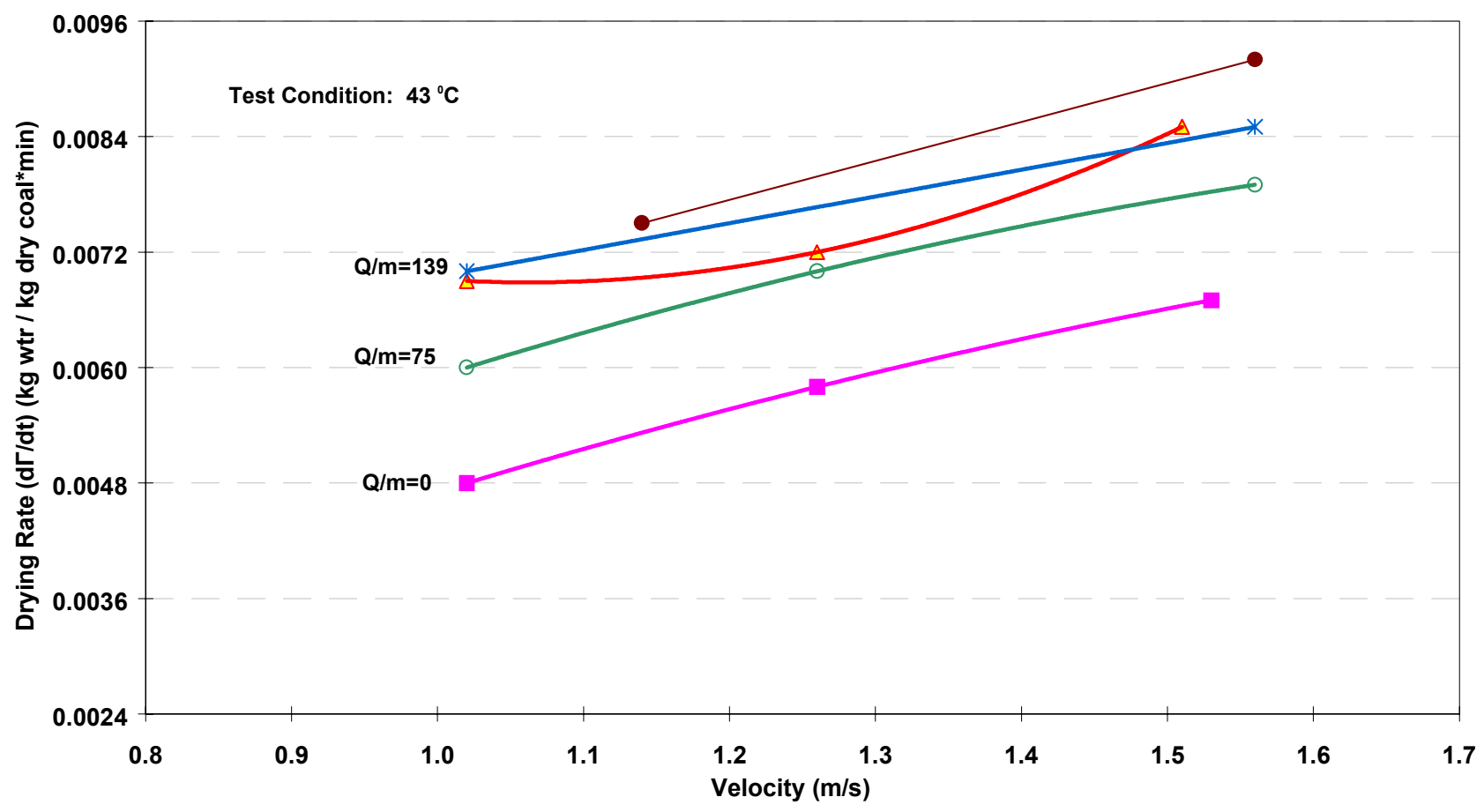

Figure 13: Drying Rate Versus Velocity and Heat Flux 


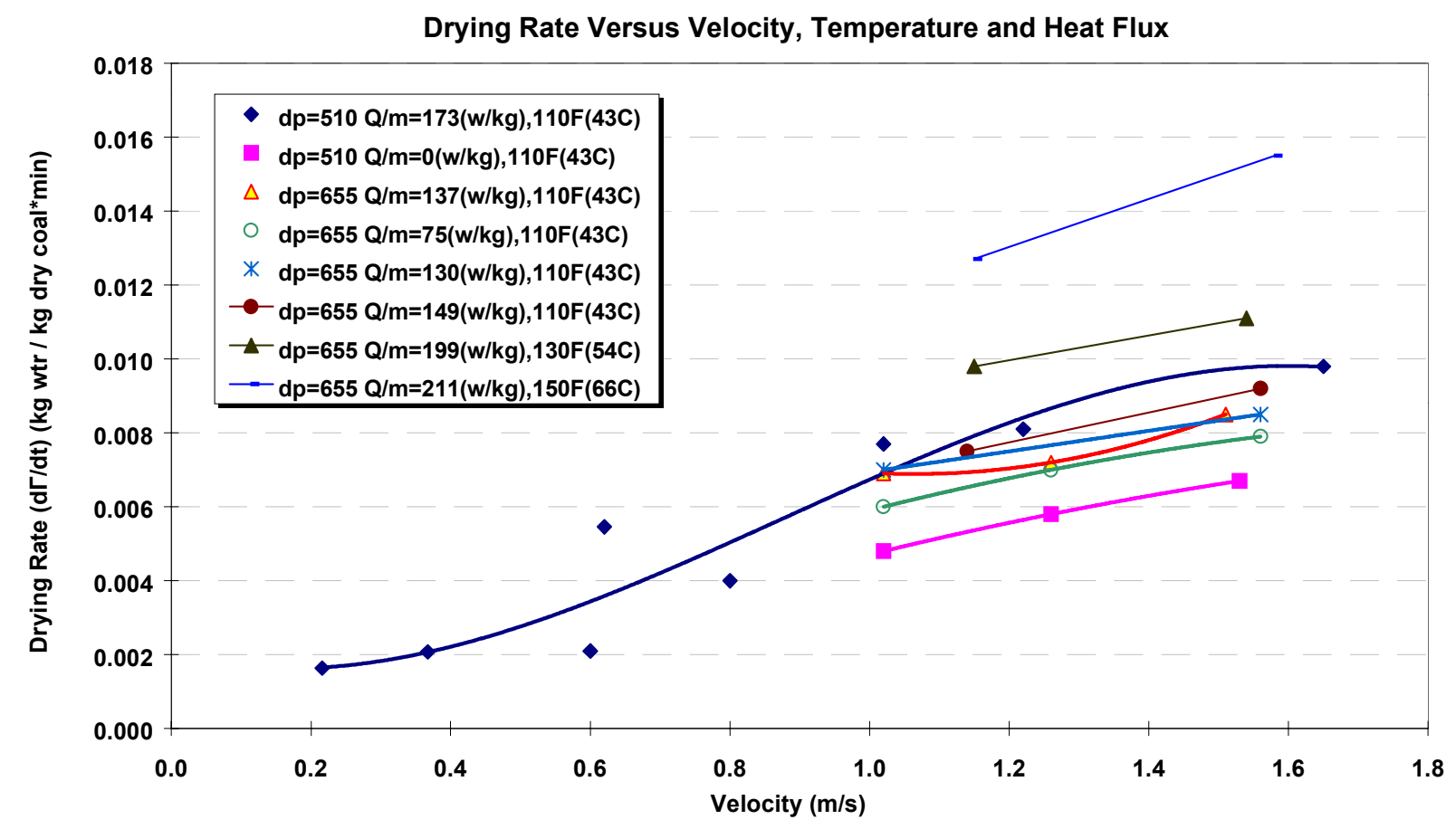

Figure 14: Drying Rate Versus Velocity, Temperature and Heat Flux

Figures 15 to 18 show more details of the drying process for one set of operating conditions (Test 34). The drying curve is shown in Figure 15. Exit air and bed temperatures (Figures 16 and 17), which were roughly equal to one another, increased by about $2^{\circ} \mathrm{C}$ over the first 30 minutes of drying. The specific humidity of the exit air decreased slightly as the air temperature increased (Figure 18).

The effects of drying temperature and velocity on $\dot{\Gamma}$, bed temperature and exit specific humidity are shown in Figures 19 to 21 . In-bed heat flux had only a small effect on bed temperature for fixed drying temperature as seen by Figure 22. 


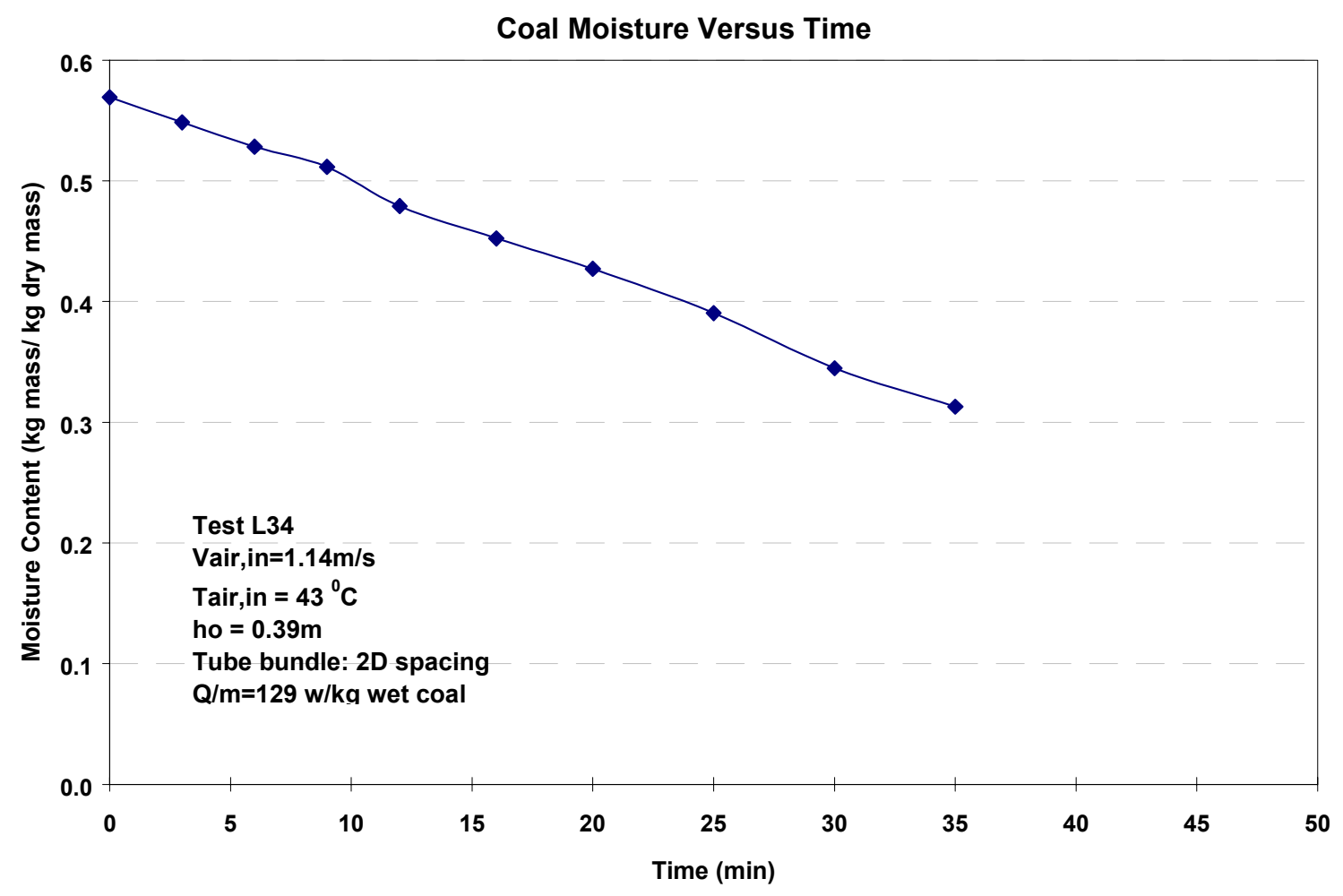

Figure 15: Coal Moisture Versus Time

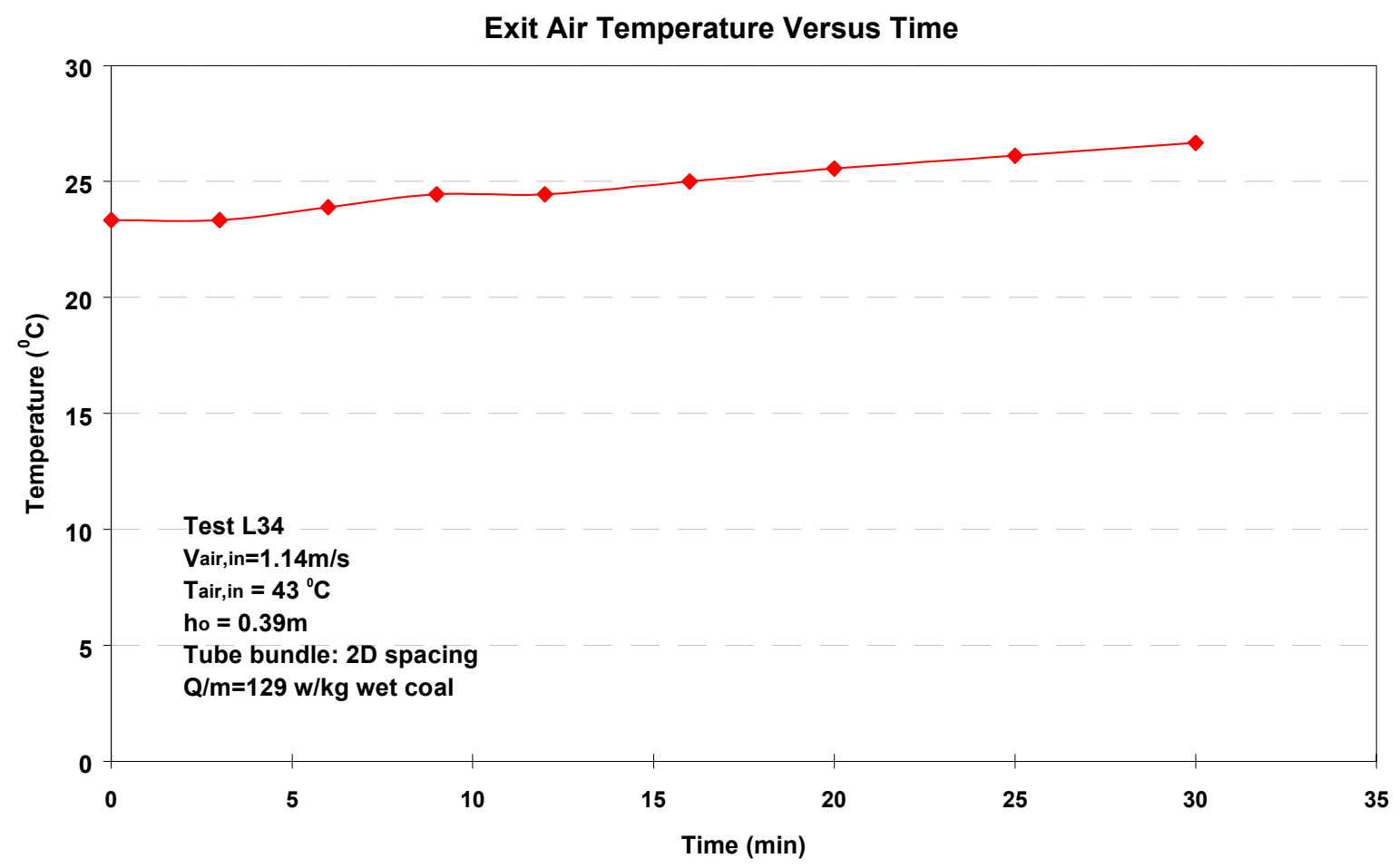

Figure 16: Exit Air Temperature Versus Time 


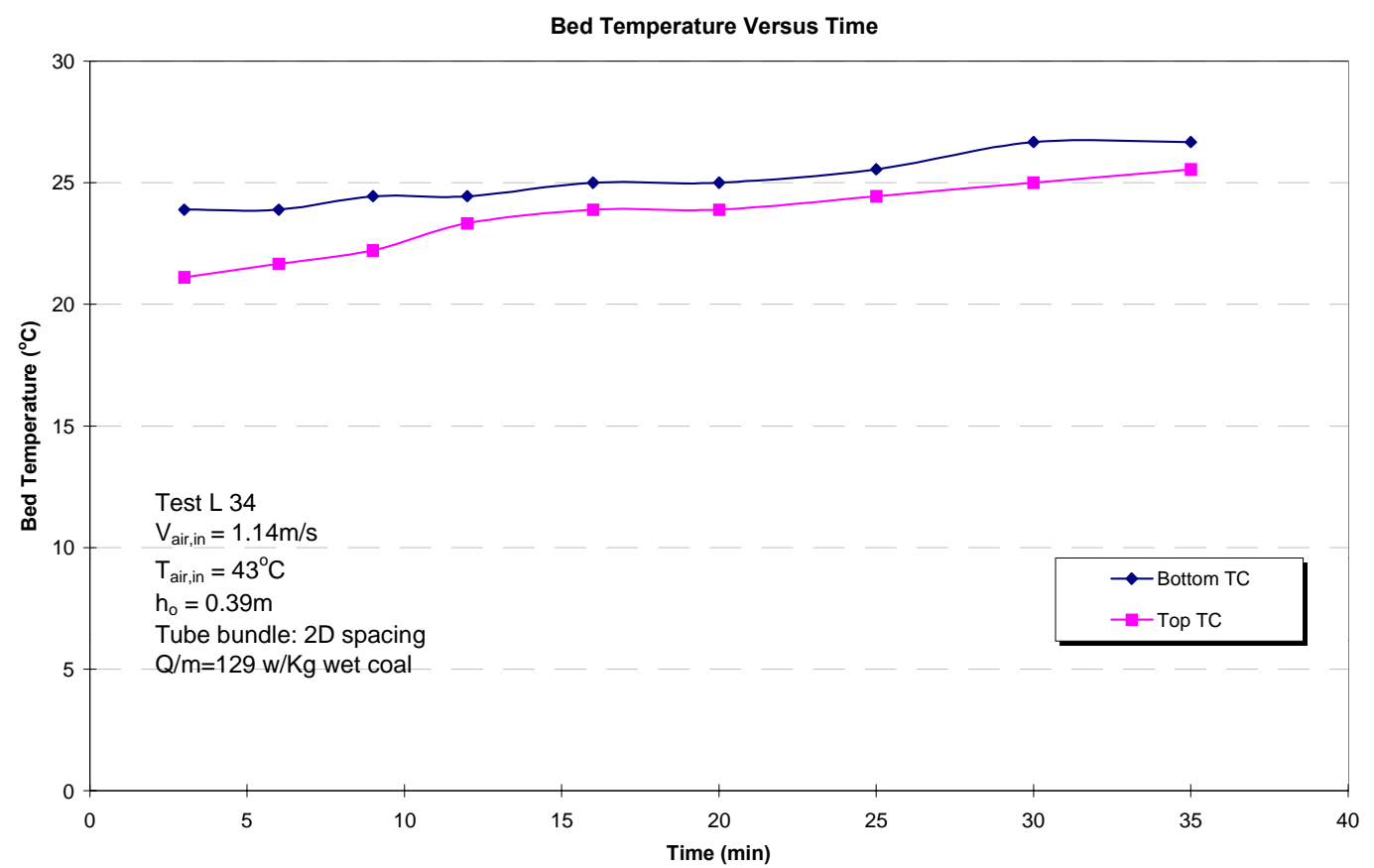

Figure 17: Bed Temperature Versus Time

Outlet Specific Humidity Versus Time

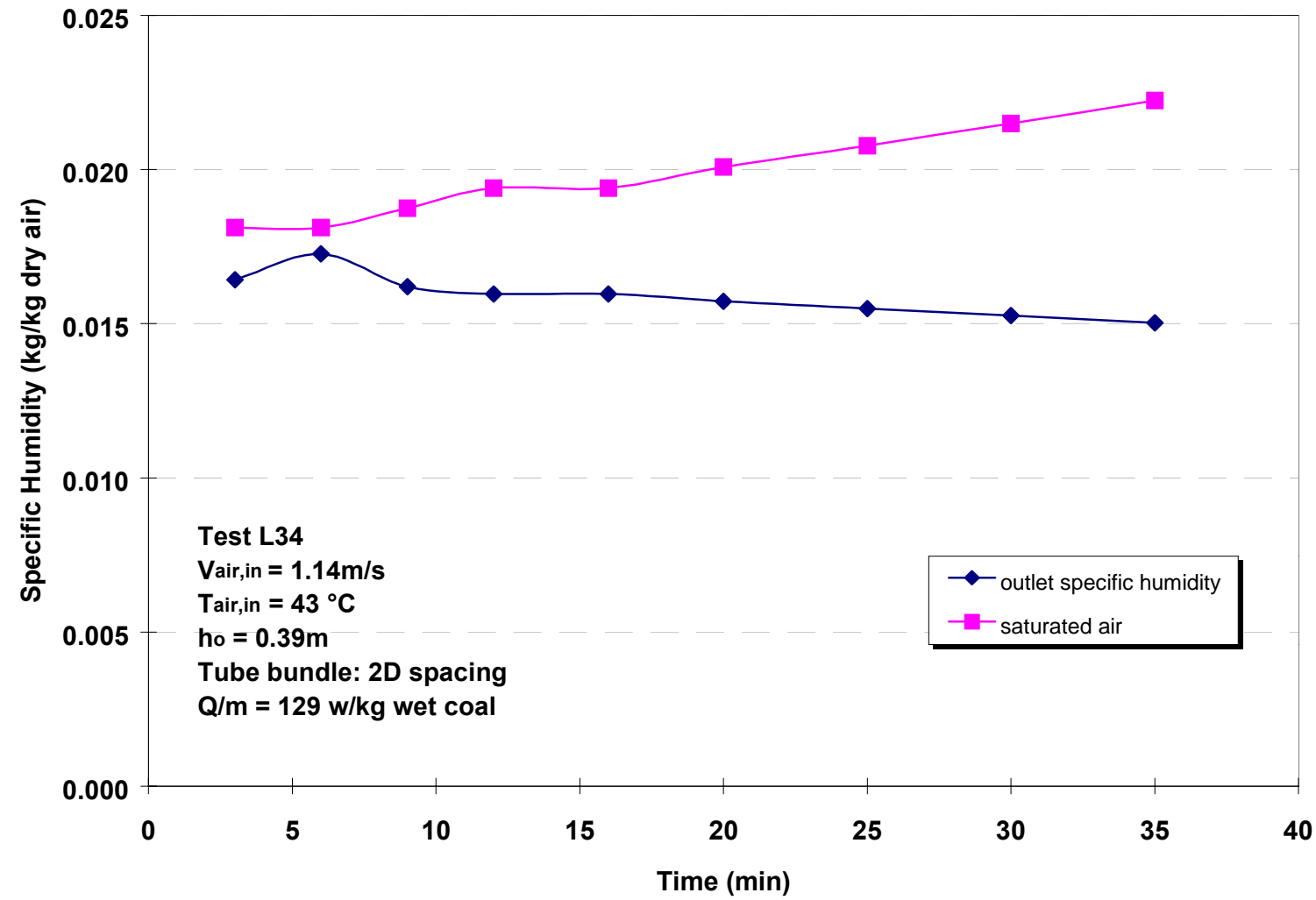

Figure 18: Outlet Specific Humidity Versus Time 
$\mathrm{d} \Gamma / \mathrm{dt}$ vs $\mathrm{T}_{\mathrm{air}, \mathrm{in}}$

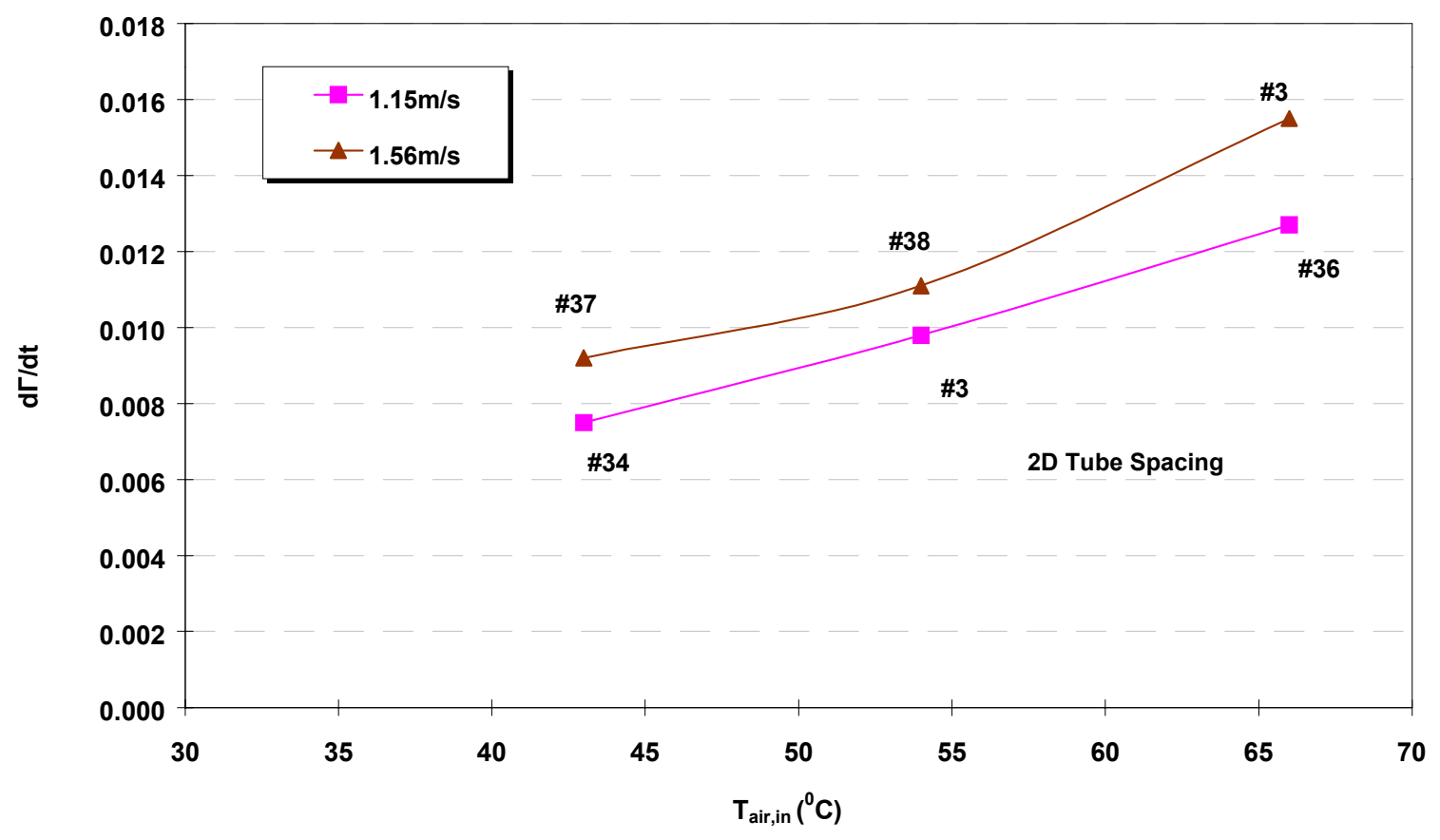

Figure 19: $d \Gamma / d t$ Versus $T_{\text {air,in }}$

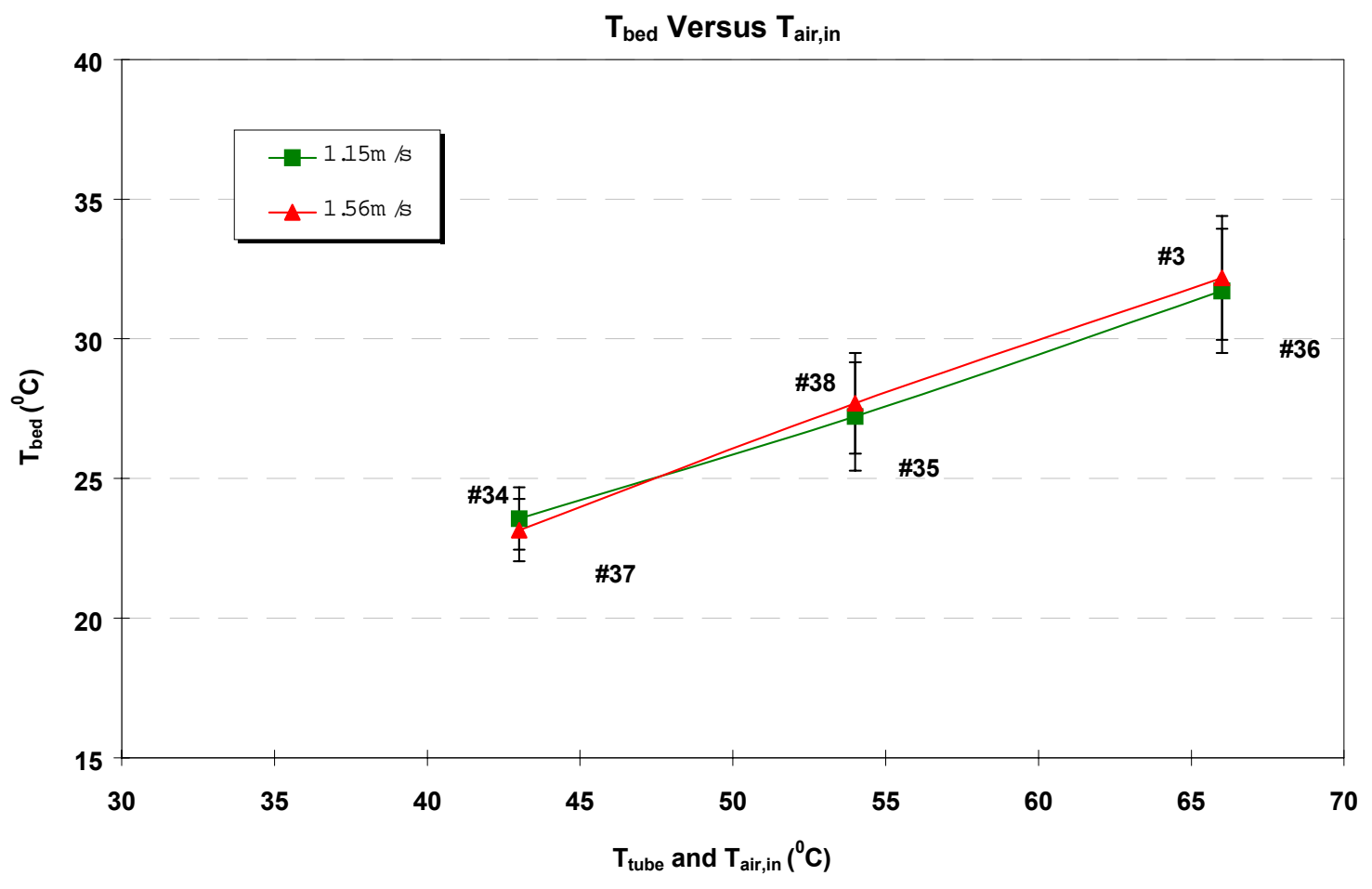

Figure 20: $T_{\text {bed }}$ Versus $T_{\text {air,in }}$ 


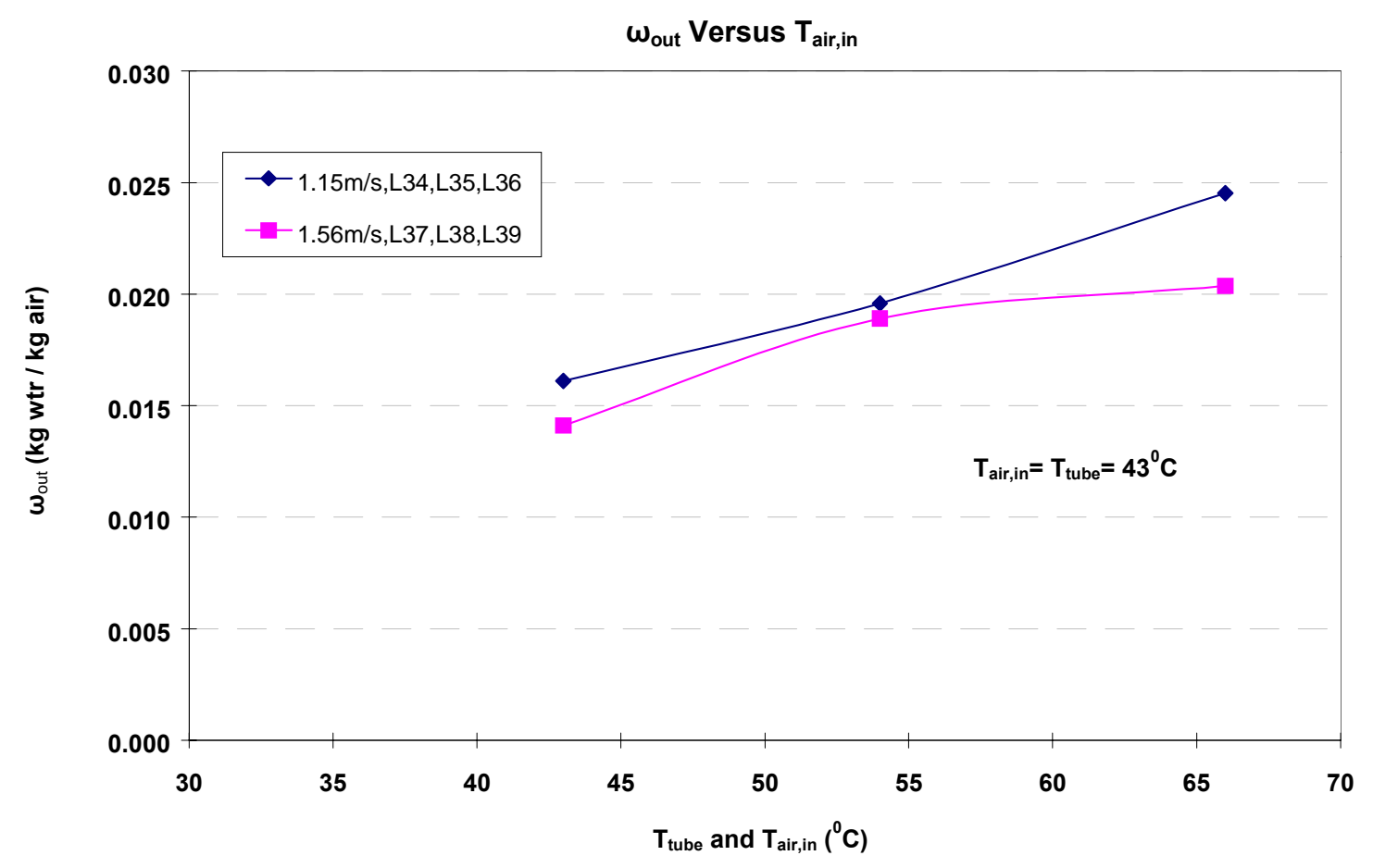

Figure 21: $\omega_{\text {out }}$ Versus $T_{\text {air, in }}$

$T_{\text {bed }}$ Versus Q/m

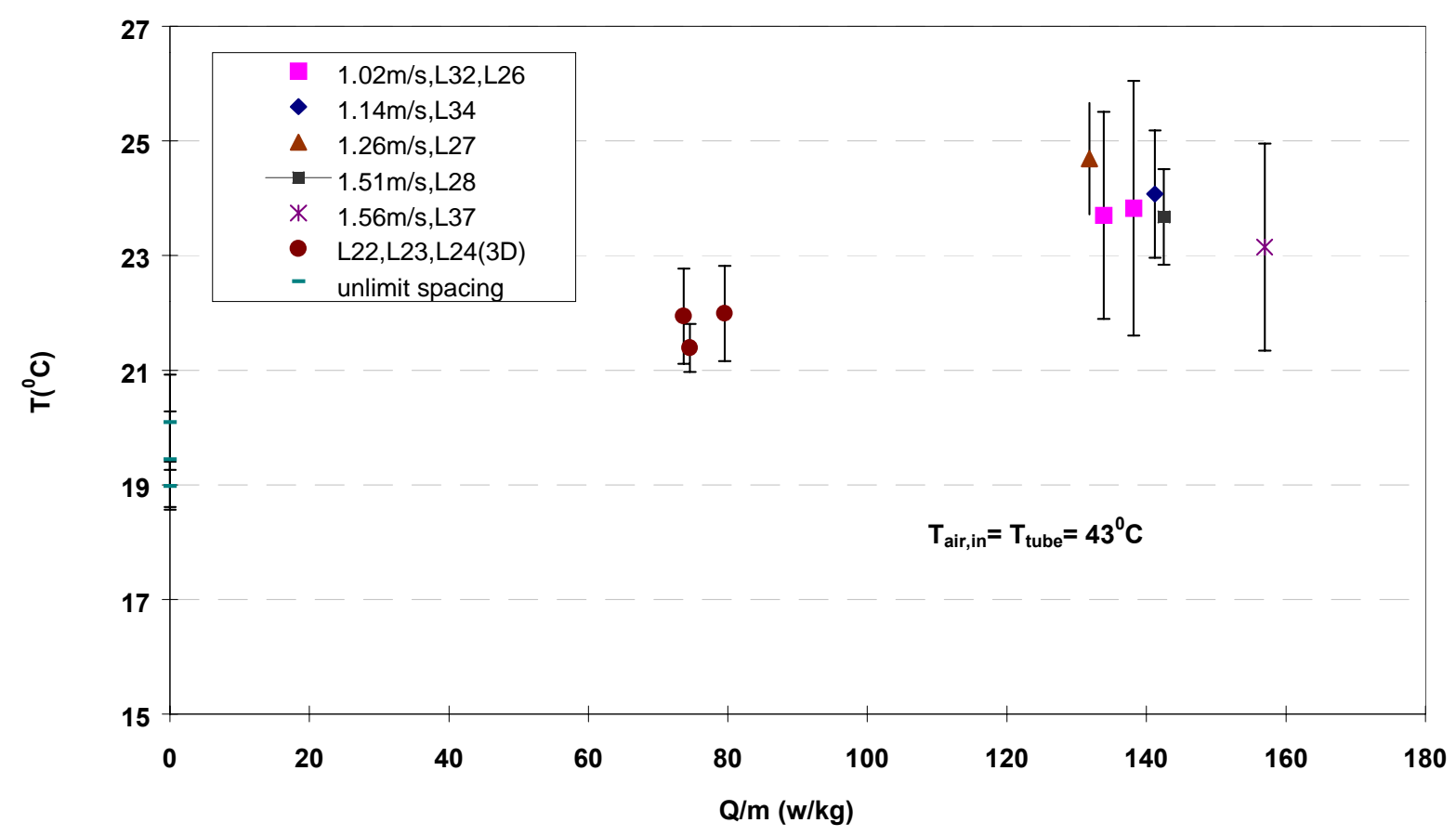

Figure 22: $T_{\text {bed }}$ Versus $\mathrm{Q} / \mathrm{m}$ 


\section{DRYING MODELS}

The task on developing models for predicting rate of drying was initiated during this last quarter. We expect to have some modeling results to report in the next quarterly report.

\section{CONCLUSIONS}

Much of the effort during the first year of the project focuses on the effects of dryer process conditions on drying rate. Having this information is key to being able to design dryers for this application, to estimate the costs of the drying system equipment and its operating costs, and to estimate the impacts of drying on cost of energy. Drying rate depends on superficial air velocity, bed depth, particle size distribution, drying temperature, heat flux from in-bed heat exchanger to bed material, and specific humidity of inlet air.

The experiments carried out during the second quarter were performed with 6.35 $\mathrm{mm}(1 / 4$ ") top size lignite. Batch experiments on drying rate were carried out as a function of superficial gas velocity, inlet air and tube wall temperature, and in-bed heat flux. In all cases, the initial drying rate was constant and then it decreased as drying progressed. The rate of drying during the constant rate period increased with velocity, temperature, and in-bed heat flux, and quantitative results on these relationships are contained in this report.

The experiments during the next quarter will measure the effects of particle feed size, bed depth and inlet air humidity on rate of drying of lignite. Experiments will also be initiated on drying of PRB coal.

Finally, work will continue on models for predicting rate of drying. 


\section{REFERENCES}

1. Bullinger, C., M. Ness, N. Sarunac, E. Levy, "Coal Drying Improves Performance and Reduces Emissions," Presented at the $27^{\text {th }}$ International Technical Conference on Coal Utilization and Fuel Systems, Clearwater, Florida, March 47, 2002.

\section{NOMENCLATURE}

\begin{tabular}{|c|c|c|}
\hline$d_{p}$ & \multicolumn{2}{|l|}{ Particle Size } \\
\hline$h_{0}$ & \multicolumn{2}{|c|}{ Settled Bed Depth } \\
\hline$\dot{\mathrm{m}}_{\text {air }}$ & \multicolumn{2}{|l|}{ Air Flow Rate } \\
\hline$M_{\text {wet coal }}$ & \multicolumn{2}{|c|}{ Mass of Wet Coal } \\
\hline$M_{D C}$ & \multicolumn{2}{|c|}{ Mass of Dry Coal } \\
\hline Qave & \multicolumn{2}{|c|}{ Average Heat Flux to Bed } \\
\hline $\mathrm{T}_{\mathrm{a}, \text { in }}$ & \multicolumn{2}{|c|}{ Air Inlet Temperature } \\
\hline $\mathrm{T}_{\mathrm{b}}$ & \multicolumn{2}{|c|}{ Bed Temperature } \\
\hline$U_{0}$ & \multicolumn{2}{|c|}{ Superficial Air Velocity } \\
\hline$V_{\text {Bed }}$ & \multicolumn{2}{|l|}{ Bed Volume } \\
\hline \multirow{2}{*}{ Y } & \multirow{2}{*}{ Coal Moisture } & $\mathrm{kg} \mathrm{H}_{2} \mathrm{O}$ \\
\hline & & $\overline{\mathrm{kg} \mathrm{H}} \mathrm{H}_{2} \mathrm{O}+\mathrm{kg}$ dry coal \\
\hline \multirow{2}{*}{$\Gamma$} & \multirow{2}{*}{ Coal Moisture } & $\mathrm{kg} \mathrm{H}_{2} \mathrm{O}$ \\
\hline & & $\overline{\text { kg dry coal }}$ \\
\hline$\dot{\Gamma}$ & Drying Rate = & $\frac{d \Gamma}{d t}$ \\
\hline$\omega$ & Specific Humid & lity of Air \\
\hline
\end{tabular}

